University of Nebraska - Lincoln

DigitalCommons@University of Nebraska - Lincoln

Faculty Publications, Department of History

History, Department of

December 2007

\title{
The Tryphê of the Sybarites: A Historiographical Problem in Athenaeus
}

Robert J. Gorman

University of Nebraska - Lincoln, rgorman1@unl.edu

Vanessa Gorman

University of Nebraska-Lincoln, vgorman1@unl.edu

Follow this and additional works at: https://digitalcommons.unl.edu/historyfacpub

Part of the History Commons

Gorman, Robert J. and Gorman, Vanessa, "The Tryphê of the Sybarites: A Historiographical Problem in Athenaeus" (2007). Faculty Publications, Department of History. 36.

https://digitalcommons.unl.edu/historyfacpub/36

This Article is brought to you for free and open access by the History, Department of at DigitalCommons@University of Nebraska - Lincoln. It has been accepted for inclusion in Faculty Publications, Department of History by an authorized administrator of DigitalCommons@University of Nebraska - Lincoln. 


\title{
THE TRYPHE OF THE SYBARITES: A HISTORIOGRAPHICAL PROBLEM IN ATHENAEUS*
}

\begin{abstract}
A large number of the most informative fragments of the Hellenistic Greek historians are transmitted by Athenaeus. Unlike the frequently jejune evidence provided by scholiasts, lexicographers and the like, these texts allow us to draw historiographical conclusions about lost writers: on this basis, scholars have posited, for example, the place of a given author in the Hellenistic 'schools' of history. The importance of Athenaeus as a source for history-writing between Xenophon and Diodorus calls for detailed study of the Deipnosophist's method of citing these lost authors. The present article focuses on Athenaeus' testimony concerning the downfall of Archaic Sybaris through luxury and excess in order to show that certain phrases, sentence patterns and even trains of thought can be reliably identified as belonging to Athenaeus rather than the cited authority. This discovery entails surprising results: traditions ascribing the destruction of Sybaris to morally corrosive luxury are late and of little historical value. More generally, the debilitating effects of luxury cannot serve as an exemplum supporting the claim that Hellenistic writers tended to explain historical events through moral causes; apparent evidence for this causal nexus is better assigned to Athenaeus than to the historians he names. In view of these conclusions, a cautious reassessment of all Athenaeus' testimony on fragmentary historians is appropriate.
\end{abstract}

THE Deipnosophistae of Athenaeus of Naucratis is one of the most important sources for our knowledge of the Hellenistic historians. Accordingly, the clearest possible understanding of Athenaeus' handling of prose fragments is of great significance to the effort of reconstructing Greek historiography between Xenophon and Diodorus. Important work has been done in recent years on this topic,' but much remains to be learned. In particular, progress can be made through an examination of the concept of $\tau \rho \vartheta \varphi \eta$. T $\rho \varphi \varphi$ ' or 'luxury' is a particularly apt focus for a study of Athenaeus and the historians of the fourth through the first centuries: the concern of these writers for $\tau \rho \cup \varphi \eta$ is often adduced to demonstrate their interest in the idea of moral causation. ${ }^{2}$ For his part, Athenaeus is deeply interested in the moral ramifications of $\tau \rho v \varphi \eta$, and his dialogue is our most abundant source in this regard. However, elements in Athenaeus that are commonly regarded as stemming from earlier authors are often identifiable, with some degree of certainty, as having been added subsequently.

In order to keep our presentation within reasonable bounds, we shall limit ourselves to a case study. Sybaris, the Achaean colony on the south coast of Italy, is the most notorious example of an Archaic city whose luxurious living brought it to ruin. Scholars have seen in the traditions on the fall of Sybaris perhaps the earliest manifestation of the theory of historical causation according to which unusual prosperity sets in motion a kind of chain reaction of decadence: from $\pi \lambda \mathrm{ov} \tau \mathrm{\tau} \varsigma$

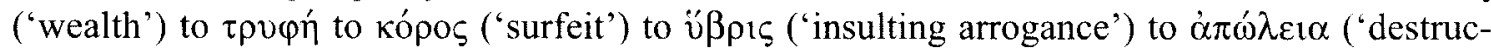
tion'). ${ }^{3}$ This theory is believed to underlie the most important historical traditions on Sybaris. Briefly put, Sybaris was said to have become a city of great wealth and luxury which, eventually

\footnotetext{
* We wish to dedicate this article to the memory of A. John Graham, who taught us to read fragments.

' Ambaglio (1990), Pelling (2000), and Zecchini (1989).

${ }^{2}$ A. Passerini (1934) 37 is insistent that the concept of $\tau \rho v \varphi$ ' leading to the destruction of the state has 'una importanza soverchiante' for Hellenistic historiography. Brown (1958) 4 notes that Timaeus especially favoured $\tau \rho \cup \varphi \dot{n}$ among moral causes. More recent scholars argue in the same vein: G. de Sensi Sestito (1988) 405, relying to a large degree on the Sybaris evidence of Athenaeus, claims that Timaeus, following the lead of earlier historians, made a quasi-systematic use of 'il motivo della tryphe
}

come chiave di interpretazione storica'. She makes the series luxury-hybris-destruction Timaeus' particular scheme for understanding events at Sybaris (p. 406). R. Vattuone (1991) 323-33 puts Athenaeus' evidence on

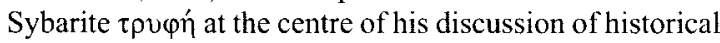
causation. M. Flower (1994) 166 finds in the same passages proof for the direct influence of Theopompus on Timaeus vis-à-vis $\tau \rho v \varphi n$.

${ }^{3}$ It is necessary to make a distinction between this theory, which holds that $\tau \rho v \varphi \eta$ leads to acts of $\ddot{0} \beta \rho ı \varsigma$ which in turn justify divine punishment, and an alternative belief that is also present in some sources: $\tau \rho v \varphi \eta$ enervates the wealthy until they fall like over-ripe fruit. 
forgetting itself, gave bloody offence both to the gods and to its neighbours. Its subsequent defeat and sack at the hands of Croton was an act of divine, as well as human, retribution. ${ }^{4}$

The $\tau \rho v \varphi \eta$ of the Sybarites is a favourite paradigm for Athenaeus. He preserves fragments on this topic from seven prose authors: Aristotle, Theophrastus, Heracleides Ponticus, Chamaeleon, Timaeus, Phylarchus and Polybius. Interpreting prose fragments is a notoriously tricky business, since it is often very difficult to decide what is to be attributed to the original author and what to the transmitting source(s). Before examining the individual fragments, it will be beneficial to make some general observations on Athenaeus' practice in this regard.

\section{PRELIMINARY CONSIDERATIONS}

In a recent study, Christopher Pelling has ably set out some of the chief perils that await anyone who wishes to make an argument using historical fragments reported by Athenaeus. Most important from our perspective is Pelling's demonstration of how Athenaeus can move from his principal authority for a given topic to other sources and then back again, all without any indication:

Athenaeus can often use a dominant, named figure only as a framework and can hang independent material on that frame: he can quote Posidonius or Theopompus, drift away and drift back again. ... All too often we fall in to the trap of assuming that the independent material belongs to the dominant frameworkfigure as well. ${ }^{5}$

Among the illustrations Pelling gives for this procedure is the case of Smindyrides of Sybaris, whom Athenaeus advances in Book 12 as an example of $\tau \rho v \varphi \eta$ :

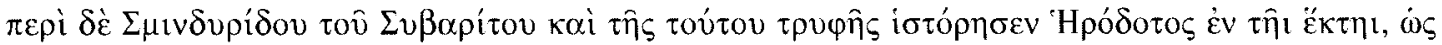

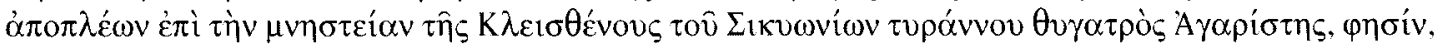

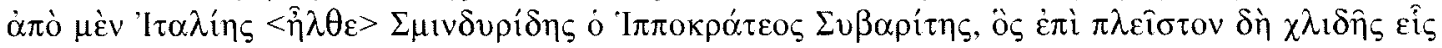

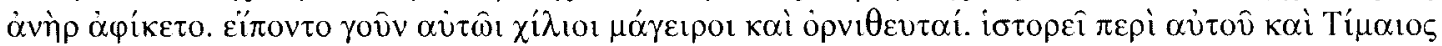

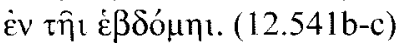

About Smindyrides of Sybaris and his luxury Herodotus tells the story in his sixth book of how he sailed to the wooing of Agariste, the daughter of Cleisthenes the tyrant of Sicyon. He says 'the Sybarite Smindyrides the son of Hippocrates came from Italy; he had reached the furthest extent of luxury'. Certainly one thousand cooks and fowlers accompanied him. Timaeus too wrote about him in his seventh book.

As Pelling points out, "if we did not have Herodotus, the sentence about cooks and fowlers would surely have been taken as a Herodotus fragment'. 'Nor should we take the 'fowler sentence' as

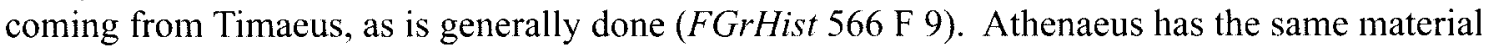
in Book 6. Here again he does not indicate that he is directly quoting from a source. ${ }^{7}$ The fowler

\footnotetext{
${ }^{4}$ Bernhardt (2003) 57 and C. Ampolo (1993) 217-22 present the clearest exposition of this view. Ampolo finds the concept of $\tilde{u} \beta p 1 \zeta$ and the belief that Sybaris was 'la polis dell'eccesso' to be the common root of a wide range of explanations for the destruction of the city. He attributes $(222,253-4)$ the origins of the $\tilde{u} \beta \rho 1 \zeta$-stories "ai nemici dei Sibariti (crotoniati e pitagorici)'. Cozzoli (1980) 136-7 and del Corno (1993) 11 also locate the origin of these stories among the Pythagoreans at Croton.

${ }^{5}$ Pelling (2000) 175.
}

\footnotetext{
${ }^{6}$ Pelling (2000) 176.

${ }^{7}$ 6.273b-c, $\dot{\alpha} \lambda \lambda$ ' ov $\Sigma \mu u v \delta$ pións ó $\Sigma v \beta \alpha p i \tau \eta \varsigma$

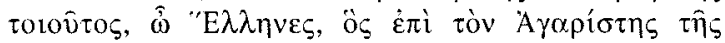

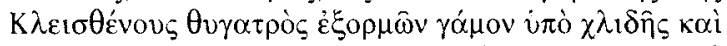

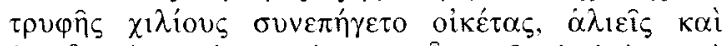

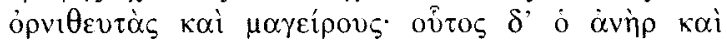

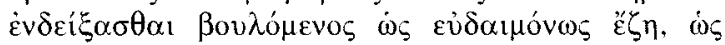

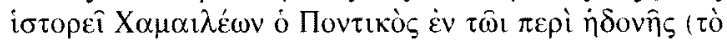

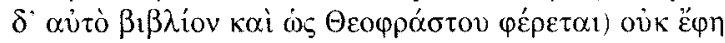

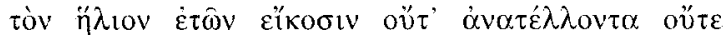


sentence 'is an extra fact hung on the framework of quotation, either just before or just after quotations, and it can simply be a fact drawn from his general knowledge'.

Thus, awareness of Athenaeus' tendency to compositional drift demands that the greatest weight be given to those passages in which the direct attribution to an author is clear. The genuineness of material that may be added to this framework will have to be judged on the basis of the picture of an author developed strictly from such clear citations. Such an approach is likely to exclude much of what is supposedly the best evidence for a tradition of Sybarite decadence.

Even in the case of fragments of indisputable attribution, there are further reasons for caution. Any historian using the testimony of the Deipnosophistae must, of course, constantly keep in mind the general admonition of P.A. Brunt that the ancients were fond of paraphrases and that these were shaped by the quoting author's intent. ${ }^{.}$Moreover, certain particularities of Athenaeus' sympotic discourse make evaluating historical material in his work especially challenging. Christian Jacob, in his penetrating introduction to the recent Athenaeus commentary, draws attention to Athenaeus' claims to be producing something new. ${ }^{10}$ These are surprising statements in a work which consists to a great extent of a web of quotations, but Jacob is able to offer an explanation. The novelty of which Athenaeus boasts arises from the paradoxical and unexpected connections among quotations. Athenaeus' characters disdain 'il ricorso alle fonti più obvie'." Instead, to answer the question of the moment, they bring to bear evidence not usually cited in a given context. If Jacob is correct in his analysis, we must expect that Athenaeus, in his quest for paradox, uses historical evidence in ways inconsistent with a straightforward reading of the original author.

Evidence is not difficult to find, as we have already seen. Introducing Herodotus' evidence on Smindyrides, Athenaeus says that the historian's topic is the $\tau \rho v \varphi \eta$ of the Sybarite. This statement might seem an alteration of minor significance, especially since in Athenaeus' own day $\tau \rho v \varphi$ ' had

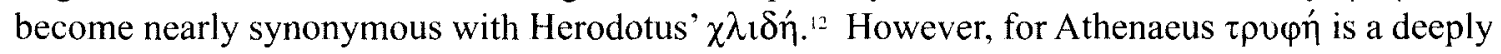
pejorative term, while an examination of the original reveals no evidence that Herodotus means to characterize Smindyrides negatively. ${ }^{13}$ As we shall see, such small changes have far-reaching ramifications.

Other cases are presented by Delfino Ambaglio, who, in order to estimate Athenaeus' reliability in fragmentary authors, has studied his use of Herodotus, Thucydides and Xenophon. Significantly, he finds distortion of sense occurring side by side with 'la riproduzione esatta di un testo'.14

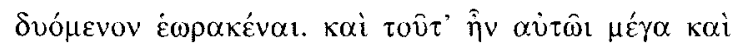

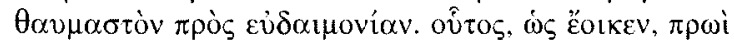

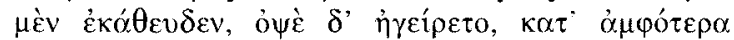
$\delta v \sigma \tau u \chi \hat{\omega} v$ ('But Smindyrides of Sybaris was not such a man, $O$ Greeks, who going off to the wedding of Agariste the daughter of Cleisthenes took a thousand slaves with him out of luxury and softness - fishers and fowlers and cooks. This is the man who wanted to demonstrate how happily he lived, as Chamaeleon of Pontus says in his $O n$ Pleasure (this same book is also ascribed to Theophrastus); he denied that he had seen the sun rise or set in 20 years. He considered this a great and wonderful mark of happiness. It seems he went to bed early and got up late, unfortunate on both counts'.) Note that Athenaeus cites Chamaeleon as authority for Smindyrides' sleeping habits, but not for the fowler sentence.

${ }^{8}$ Pelling (2000) 177.

${ }^{\circ}$ Brunt (1980) 478-9.

${ }^{10} \mathrm{Jacob}(2001)$ ci with reference to $6.222 \mathrm{a}, \dot{\varepsilon} \pi \varepsilon 1 \delta \dot{\eta}$

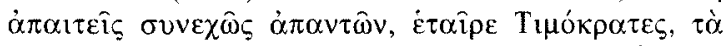

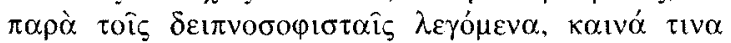

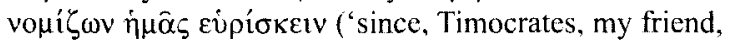

when we meet you continuously demand what the Deipnosophists said, thinking that we discover new things ...'), and similar material at $13.613 \mathrm{c}-\mathrm{d}$ and 15.665a.

"Jacob (2001) cii.

12 Notice that Athenaeus conjoins $\tau \rho \cup \varphi \eta$ to $\chi \lambda \imath 1 \delta \eta$ when he introduces Smindyrides at $6.273 \mathrm{~b}-\mathrm{c}$.

${ }^{13}$ We cannot be sure precisely what Herodotus means by $\chi \lambda{ }_{1} \delta \eta$, since it occurs only here in the Histories. Nevertheless, it is unlikely that he is characterizing Smindyrides with a strong pejorative, given that he is

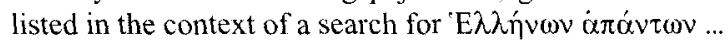
tòv äpıotov. Note as well that Athenaeus gives the impression that Herodotus' focus is on Smindyrides and his decadence, when the historian's point is the rise of the Alcmaeonids. In fact, as Bernhardt (2003) 136-7 points out, Herodotus usually does not show great interest in the moral effects of luxury: for example, he does not criticize either Croesus or Polycrates of Samos for their way of life, nor does he use their opulence to help explain their sudden downfalls.

${ }^{14}$ Ambaglio (1990) 52. 
Athenaeus used 'facts' attested by a historian to support the argument of his dialogue, without regard for whether such a use is consistent with the meaning of the passage in its original context. ${ }^{15}$ For example, at 6.75 Herodotus relates the suicide of Cleomenes of Sparta, who, though physically restrained and under guard, managed to obtain a knife and fatally mutilate himself. Athenaeus

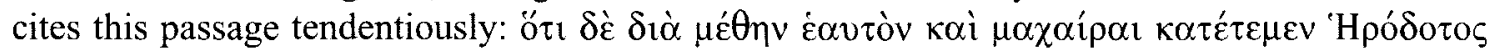
i $\sigma \tau$ óp $\sigma \varepsilon$ (10.436f, 'Herodotus says that he cut himself up with a knife out of drunkenness'). Although there is no indication in the text of Herodotus that Cleomenes was drunk at the time, and further, although Athenaeus knows of Histories 6.84, where Herodotus rejects the Spartan tradition that Cleomenes' madness was caused by a preference for strong wine which he learned from the Scythians, Athenaeus clearly implies that it is Herodotus' view that Cleomenes acted $\delta \dot{\alpha} \mu \varepsilon^{\prime} \theta \eta v .{ }^{16}$

In a passage of special interest to our investigation, Athenaeus (4.144c) cites Xenophon's Agesilaus 9.3, where the austere lifestyle of the Spartan is compared to that of the Persian kings. Once again Athenaeus characterizes the purport of the passage he quotes in his own terms: Xenophon, he says, is writing $\pi \varepsilon \rho i \tau \hat{\imath} \varsigma \tau \rho v \varphi \hat{\eta} \varsigma$ of the Persians, though the word does not occur in the Agesilaus. Of course, in this instance a reader may judge that Athenaeus is offering an accurate interpretation of Xenophon's text: Xenophon considers the Greek's lifestyle to be morally superior to Persian luxury, and for Athenaeus $\tau \rho v \varphi \eta$ is unquestionably a moral failing.

Thus, study of Athenaeus' use of extant historians gives the unsurprising result that sometimes the Deipnosophist interprets his sources in a manner that seems to us unobjectionable; at other times, the view he offers seems inconsistent or even at cross-purposes with the argument of the original. But as obvious as this information may be, it gains serious significance when we turn to evaluate the evidence for Athenaeus' fragmentary authors. There we would give a great deal to be able to discern when our author is following his original closely and when he is elaborating.

\section{2. 'RUNNING AGROUND ON LUXURY'}

A necessary first step in that direction is the identification, in passages where Athenaeus is citing historians, of patterns of thought or diction which we can assign with some degree of confidence to Athenaeus rather than his source. Note that in the examples from both Herodotus and Xenophon that are given above, the significant alterations made by Athenaeus occur in sentences in which Athenaeus introduces the authority of the author in question. ${ }^{17}$ If we examine introductory or transitional passages in Athenaeus' discussion of $\tau \rho \nu \varphi \eta$, we find reason to suspect that a similar elaboration has taken place.

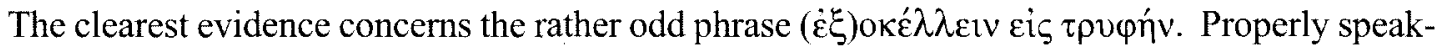
ing, $\dot{\varepsilon} \xi_{\text {o }} \varepsilon \dot{\varepsilon} \lambda \lambda \varepsilon \iota v$ is a navigational term meaning 'to run aground'. Athenaeus' expression thus might be rendered 'to shipwreck onto luxury' or the like. In the extant part of the Deipnosophistae,

\footnotetext{
15 Ambaglio (1990) 53: Athenaeus, "in questo caso come altrove, mostra di usare il testo di Erodoto senza riguardo alcuno per il suo significato'. A humorous illustration of Ambaglio's point is the interpretation of Herodotus that Athenaeus gives at $3.78 \mathrm{e}$. In the relevant passage (1.71.3), Herodotus relates the advice given to Croesus by the Lydian Sandanis: Croesus should not attack the Persians, because the Persian land was poor, with nothing to offer Croesus in case of a Lydian victory: ouk

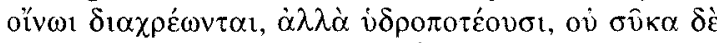

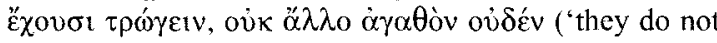
use wine, but are water drinkers; they have neither figs to eat, nor any other good thing'). Athenaeus quotes the paragraph containing Sandanis' advice with the following

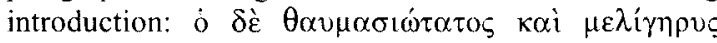

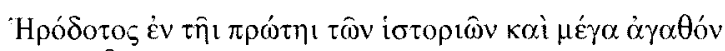

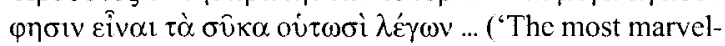
lous and sweet-voiced Herodotus in Book 1 of his Histories also says that figs are a great good, and I quote ...').

${ }^{10}$ Even if $\delta \grave{\alpha} \mu \varepsilon \dot{\theta} \eta \eta v$ is taken to mean a chronic disposition toward drunkenness rather then a particular drunken episode, it is not Herodotus' version, for he indicates that he prefers the explanation of the majority of Greeks, according to which Cleomenes was driven mad as divine retribution for tampering with the Oracle. Athenaeus quotes from this passage $(6.84)$ at $10.427 \mathrm{~b}$, where he is interested in the Scythian connection.

${ }^{17}$ Brunt (1980) 479 and Jacob (2000) xcvi each draw attention to the difficulties presented by the onsets and conclusions of fragments. 


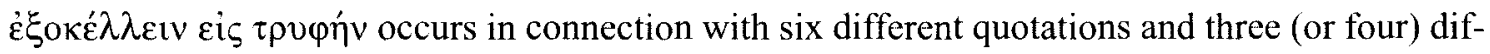
ferent authors:

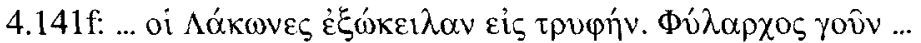

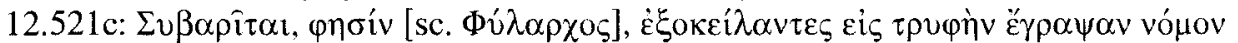

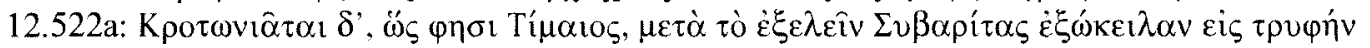

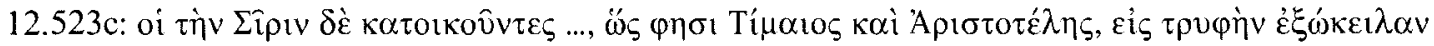

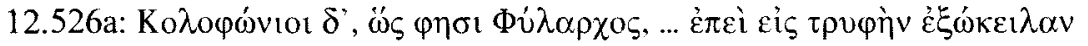

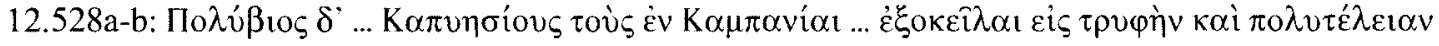

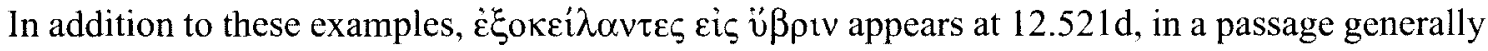

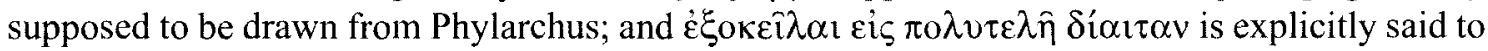
come from Nicolaus of Damascus at 12.543a. Thus, Athenaeus associates the construction in question ( $\dot{\varepsilon} \xi_{0 \kappa} \varepsilon \dot{\lambda} \lambda \varepsilon \varepsilon v$ completed by a preposition whose object is $\tau \rho \cup \varphi \eta \dot{~ o r ~ a ~ s i m i l a r ~ m o r a l ~ t e r m) ~}$ perhaps with Aristotle and without doubt with Timaeus, Phylarchus, Polybius and Nicolaus.

A brief examination of the history of this usage is instructive. If we leave aside for the moment the examples quoted in the previous paragraph, there are no securely attested instances of our

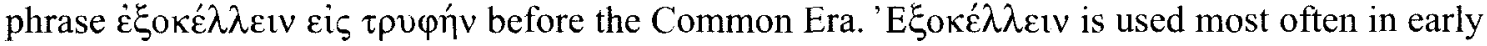
literature in its proper sense to refer to actual groundings by ships and also animals such as dolphins and snakes. ${ }^{18}$ The remaining uses from before the Common Era are metaphorical and worth examining in detail, for there are only six of them. Aeschylus (Supp. 438) uses the phrase intransitively to describe a predicament ( $\delta \varepsilon \hat{v} \rho \circ \delta$ ' $\dot{\varepsilon} \xi_{0} \kappa \dot{\varepsilon} \lambda \lambda \varepsilon \tau \alpha \mathrm{l}$, meaning 'It has come to this moment of crisis'), which he goes on to explain: Pelasgus must choose between waging war against one side or the other. In Euripides' Tro. 137, when Hecube uses the phrase ( $\dot{\varepsilon} \varsigma \alpha \dot{\alpha} \nu \delta$ ' $\dot{\xi} \xi \omega \kappa \varepsilon \imath \lambda$ ' $\alpha$ ' $\tau \alpha v$, 'I have shipwrecked in so much ruin'), she does so in the context of a direct address to the very ships that brought the Greeks to Troy. Thus her usage is set in a strictly nautical framework. Isocrates three times uses the verb. At 7.18, the results of bad government are characterized as a shipwreck. ${ }^{19}$ At 15.268 , he advises young men not to get bogged down in the arguments of the sophists $(\mu \eta \delta$ '

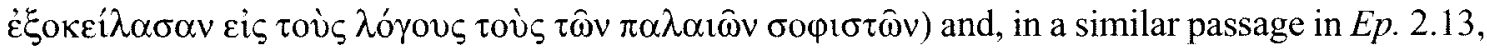
he promises to end a discussion too extensive for a letter instead of shipwrecking on lengthy dis-

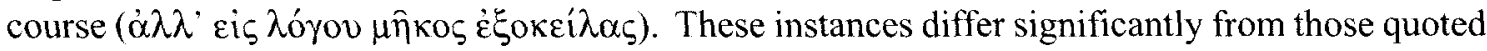
in Athenaeus, because they are a matter of running aground on something external to the subject (bad luck or the like), not on the subject's own proclivity for vice.

The last passage from this period, Polybius, Hist. 4.48.11, rings an interesting change on the early metaphorical uses. The context describes Achaeus, viceroy in command of Asia west of Mt Taurus. He avenged the assassination of King Seleucus, and usurped the throne from the Seleucid heir in $220 \mathrm{BC}$, but did not maintain his position long. He was captured and executed as a traitor

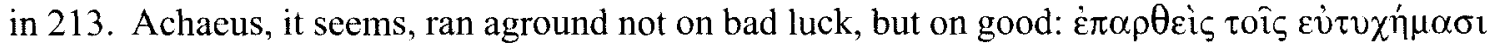

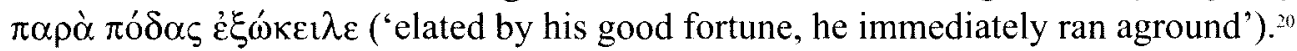

${ }^{18}$ The literal uses of the word that occur before the Common Era are: Aesch. Ag. 666; Hdt. 6.16.1, 7.182.1 bis, 8.84.2; Thuc. 2.91.4, 4.11.4, 4.12.1, 4.26.7, 8.102.3; Eur. IT 1379; Xen. Anab. 7.5.12; Arist. Hist Anim. 533b and 631 b, Mir. 844a; Nicander, Ther. 295 and 321; Polyb. Hist. 1.20.15, 1.51.9, 4.41.2; Diod. Sic. 1.31.4, 12. 62.3, 13.13.6, 20.87.2; Dion. Hal. 20.9; Strabo 9.5, 16.3.

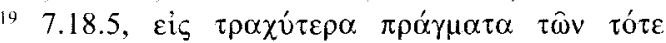

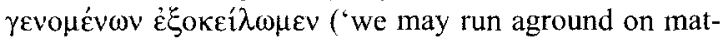
ters more rugged than the ones we faced then').
${ }^{20}$ It is possible to see in this passage a step toward the usage evident in Athenaeus, since in the later author good fortune, riches, etc. often are precursors to shipwrecking on some moral failing. However, this example seems to us a closer parallel to the earlier metaphorical uses than to the later ones: running aground on good fortune is simply a witty inversion of the more straightforward use that we have seen in Euripides and Isocrates. No serious moral culpability in Achaeus is necessarily entailed, but merely an inability to manage affairs in his new position. By contrast, moral blame on the part of the subject is regularly part of the usage later. 
For a clear parallel to our examples from Athenaeus one has to wait until the writings of Philo in the first century $\mathrm{AD}$. While he never uses the word for a literal shipwreck, it is a favourite turn of phrase for moral failings, in particular the indulgence of appetites that are better kept in check..$^{21}$ In this connection, it may be significant that Philo elaborates the metaphor, as if he might have expected it to be unfamiliar to his readers: $:^{22}$

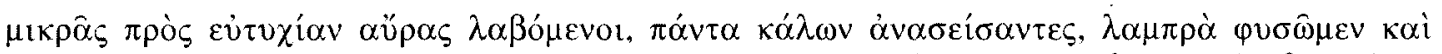

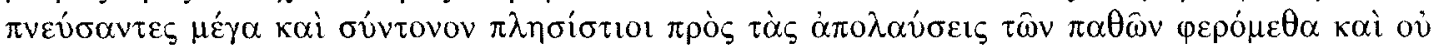

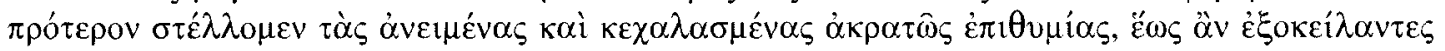

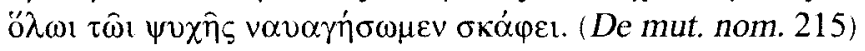

Catching the smallest breezes blowing towards good fortune, shaking out every reef, we blow a keen breeze and puffing to our utmost we move with full sails toward the enjoyment of our passions; we don't stop our slack and uncontrollably loose desires until, running aground, we shipwreck the whole vessel of our soul.

It is striking that, after Philo, the usage is adopted by that other important Jewish writer of the late first and early second century AD, Josephus, who uses it almost entirely in a moral sense..$^{23}$ In Josephus, the shoals are more broadly defined to include general savageness and madness. ${ }^{24}$

After these early metaphorical appearances, the expression re-occurs with some frequency in a wide range of authors of the first and second centuries AD and beyond, in order to describe all variety of vice, including delicate living ( $\alpha \beta \rho \circ \delta i ́ \alpha ı \tau o v)$, dice, drunkenness, shamelessness and pleasure. It became a preferred expression for Plutarch, Cassius Dio and Clement of Alexandria especially. For example, Plutarch uses it nine times metaphorically, seven of which are applied to vice, while he uses the word literally only four times. ${ }^{25}$ Omitting fragments preserved in later authors, Cassius Dio has but two literal uses (54.21 and 75.16) and ten metaphorical ones. ${ }^{26}$ Clement employs the word ten times and applies it only to vice. Interestingly enough, he for the first time outside of Athenaeus relates the phrase to $\tau \rho v \varphi \eta$ (at Paed. 3.8.44.1 and 3.11.53.2).?

${ }^{21}$ Of the nine instances in Philo, two have a general moral referent implying vice (Legum allegoriarum 2.60.7; De exsecrationibus 170 ), and the other seven are more specific: things eyes should not be looking at (De agr: 34.5 ); love of unattainable things (De confusione linguarum 7.5); lust (De somniis 1.246); intemperate language, gluttony and licentiousness (De somniis 2.147); appetite and gluttony (De somniis 2.211 ); general incontinence (De specialibus legibus 2.135); passions (De mut. nom. 215).

${ }^{22}$ Of course, this is only one possibility. The ability to revitalize a moribund metaphor is a mark of a skilled writer.

${ }^{23}$ Save for one passage about the landing of the ark, in which he is citing from Nicolaus of Damascus ( $A J 1.95)$.

${ }^{24}$ His characters shipwreck upon: envy (Vit. 123.1); crimes like plotting against one's father $(A J 17.113)$; madness ( $B J 4.261 .2$ ); savageness ( $B J 4.381 .2$ ); and even, in the case of the Emperor Nero, the theatre (BJ 2.251.2).

${ }^{25}$ Metaphorical shipwrecking on stories, similar to Isocrates' uses: Plut. De facie in orbe lunae 940f6; De sollertia animalium $985 \mathrm{c} 3$. Metaphorical, describing vice: Timoleon 36.8 .4 (ambition); De liberis educandis $5 \mathrm{~b} 9$ (dice and partying); Quaestiones conviviales $654 \mathrm{e} 6$ (hybris); Lucullus 38.4 (terrible things (Marius' later acts));
Brutus 1.2 (rage); Marius 2.4 (savageness and wildness), 45.10 (strange delusion). Literal: Septem sapientium convivium 160f7, 161a3; De gloria Atheniensium 347b2; De sollertia animalium $981 \mathrm{bl}$.

${ }^{26} 19.62 .1$ (delicate living); 24.83 .2 (the worst thing); 25.85 .1 (evil); 55.16 .3 (high birth, pride of wealth, loftiness of honours, arrogance of bravery, conceit of power); 57.13 (Tiberius ran aground when his rival, Germanicus, was removed); 58.23 (Tiberius asked the Senate not to give Gaius premature honours lest he run aground) 67.14.2.2 (the things of the Jews); 79.3.3.2 (the most shameful and illegal and polluted things); 141.13 (most dainty things); 286.13 (dainty living); S223.23 (things of the Jews).

${ }^{27}$ Also: Paedagogus 2.1.4.1 (desserts), 2.2.28.3 (pleasure), 2.8.61.1 (pleasure and relaxation), 3.2.10.3 (shamelessness), 3.8.44.1 (licentiousness), 3.11.53.2 (excess); Stromata 3.5.41.2 (pleasure); Quis dives salvetur 40.3 .2 (evil). Additional authors employing this idiom include: Herodian for drunkenness (Ab excessu divi Marci 5.7.6), faults (6.1.5), and tyranny (7.10.2); Aelius Aristides for

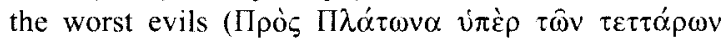
149.20); Pausanias for ignorant desire (8.24.9); and Aelian

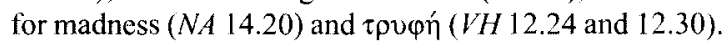


Given this evidence, it seems best to locate the source of the occurrences of $\dot{\varepsilon} \xi_{\text {o }} \varepsilon \dot{\varepsilon} \lambda \lambda \varepsilon t v \varepsilon \dot{\zeta} \zeta$ $\tau \rho \cup \varphi \eta v$ in Athenaeus in that writer's own milieu. Such an interpretation is supported by a further consideration: it stretches credulity to believe that Athenaeus, in selecting examples of $\tau \rho v \varphi \eta$ from Timaeus, Phylarchus and the rest, would by some coincidence quote so many instances of what could not have been anything but a rare phrase. Thus we conclude that $\dot{\varepsilon} \xi_{\text {o }} \varepsilon_{\varepsilon} \lambda \lambda \varepsilon ı v \varepsilon i \varsigma \tau \rho v \varphi \dot{v} v$ represents an elaboration applied to the evidence cited by Athenaeus, and we should be careful not to attribute these words to the authorities named. ${ }^{28}$

Once we begin to discern Athenaeus' modus operandi, it is possible to identify other turns of phrase that are likely to constitute later interpretation rather than the evidence of the original. One

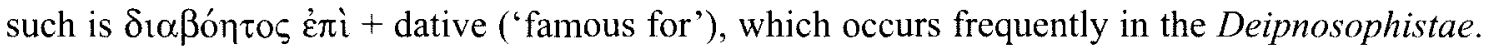

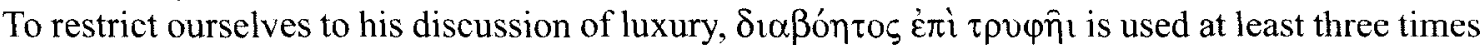
in a way that might lead the reader to assume that these words are part of the source's evidence, though they clearly are not: $11.496 \mathrm{e}$, ascribed to Nicander of Chalcedon; $12.518 \mathrm{c}$, to Clearchus of

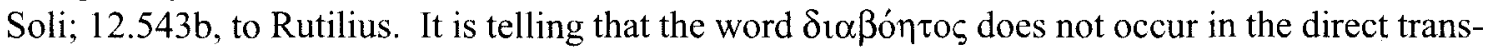
mission of any authors writing before the Common Era, whereas suddenly, in the first and second

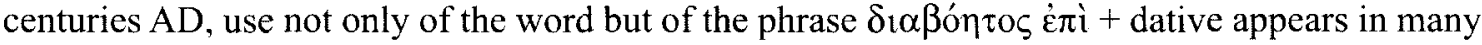
places, particularly in Plutarch, Josephus, Dio Chrysostomus, Clement of Alexandria and Origen. ${ }^{29}$ Athenaeus shows by far the most inclination for the phrase: it occurs fifteen times in his Deipnosophistae, all but one of which describe fame derived from derogatory traits: luxury most frequently, but also delicate living (ó $\psi \circ \varphi \alpha \gamma^{\prime} \alpha$ ), flattery, excessive eating, softness and feasting. ${ }^{30}$

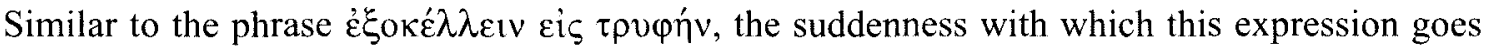
from, at most, very limited usage to a sudden proliferation in the Common Era suggests that it

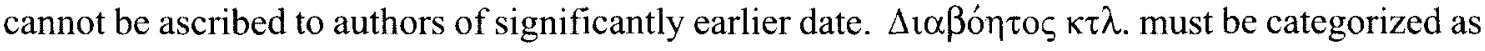
non-original. ${ }^{31}$

The last example of expressions of this sort that we shall examine is not a distinct phrase, but rather a pattern which, though clear, allows a significant degree of variation. Throughout the Deipnosophistae we find sentences with the following elements: a verb of motion (e.g. है $\rho \chi \mu \alpha \mathrm{l})$ with a dependent $\varepsilon i \zeta$; a neuter singular pronoun as the object of $\varepsilon i \zeta$; dependent on the pronoun, a genitive noun denoting the name of a vice; a result clause indicating the extent of the vice ('He went so far into vice that ...'). Once again we limit our examples to those involving $\tau \rho v \varphi \eta$ :

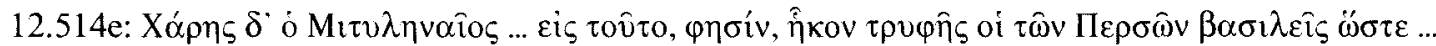

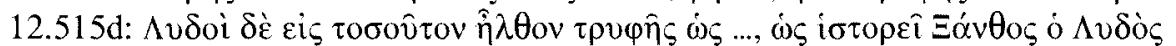

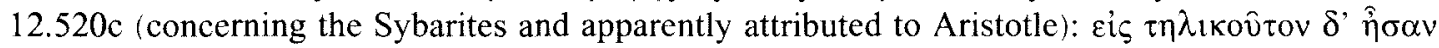
$\tau \rho \cup \varphi \hat{\eta} \varsigma$ غ̇ $\lambda \eta \lambda \alpha \kappa o ́ t \varepsilon \varsigma \dot{\omega} \varsigma \ldots$

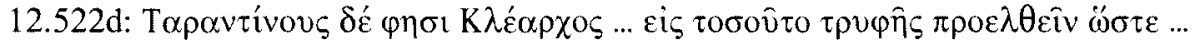

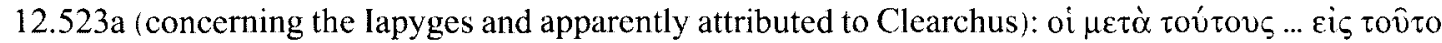

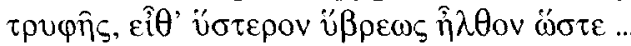

${ }^{28}$ Michael Flower (1994) 166, for example, suggests that Timaeus "coined the evocative phrase "to run aground into luxury". However, it would be difficult to explain why this coinage - apparently felicitous enough to be repeated by Phylarchus and Polybius - would disappear from our view for 250 years (if we ignore argumenti causa Athenaeus' evidence) only to re-emerge with a flourish in Philo.

${ }^{29}$ Examples with the preposition include: Plut. LuC. 6.2; Josephus, $A J 9.182$; D. Chrys. 3.72, 33.48; Clem. Al. Exc. Theod. 4.75.3; Orig. Cels. 1.29.33. It occurs in many lesser authors as well, with and without the غ̇ंí.
${ }^{30}$ Ath. Deipn. 3.100c, 6.252f, 8.338b, 9.401c, $11.496 \mathrm{~d}$, $11.509 \mathrm{c}, 12.510 \mathrm{~b}, 12.513 \mathrm{f}, 12.518 \mathrm{c}, 12,527 \mathrm{c}, 12.543 \mathrm{~b}$, $13.588 \mathrm{~b}, 15.690 \mathrm{~b}$. The single exception to the negative activities is in the epitome of Book $1(1.14 \mathrm{e})$, where Demoteles and Chairephon are famous, along with people such as Nausicaa, for being ball players. The wording may be that of the epitomizer rather than Athenaeus, of course.

"That it is part of Athenaeus' own idiom is probably entailed by the occurrence of the phrase in passages that belong to the symposiastic framing dialogue, e.g. $510 \mathrm{~b}$, the introduction to Book 12. 
Other parallels could be adduced, whether about different vices or departing from the pattern to some degree. This list, however, will suffice to establish that we are justified in suspecting that any expression of this sort is a later addition.32 Further study would no doubt reveal other such phenomena, but it is already obvious that any characterization of motives or the like that Athenaeus applies to a historical fragment must be treated with extreme scepticism, even when worded as part of the quotation. In view of the demonstrated tendency in the text of the Deipnosophistae sometimes to misrepresent the tenor of historical evidence, the opinion of the named source must be identified only on the basis of the facts related in the fragment, where these can be acertained.

Interpretations of Athenaeus' evidence on Sybarite $\rho \cup \varphi \eta$ face one more serious difficulty. In the preceding paragraphs we have for simplicity's sake said that it was Athenaeus who adjusted the thrust of his historical sources. It is possible that it is more accurate to lay at least part of the responsibility on an intermediate source. Although the question of Athenaeus' use of intermediaries is extremely complicated and perhaps overwrought with scholarship, nevertheless we must approach it briefly, since pertinent evidence has been so far overlooked in the literature.

We have noted above the existence of a passage cited from Nicolaus of Damascus in which the $\dot{\varepsilon} \xi_{\text {oK }} \hat{\imath} \lambda \lambda \varepsilon \imath \mathrm{v}$ expression is used. We must now give the quotation in full:

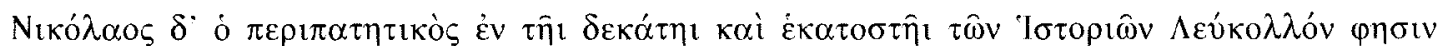

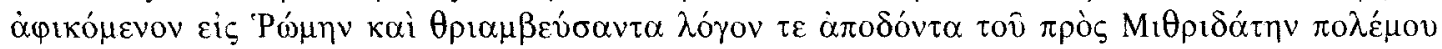

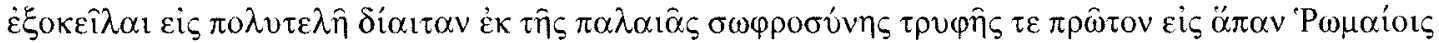

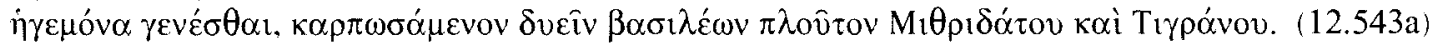

Nicolaus the Peripatetic in the one hundred and tenth book of his Histories says that Lucullus, when he had arrived in Rome and celebrated a triumph and given an account of his war against Mithridates, ran aground upon an extravagant mode of life instead of his old moderation and, enjoying the wealth of two kings, Mithridates and Tigranes, he became the very first to lead the Romans into luxury.

From the evidence we have gathered in the preceding paragraphs, we may conclude that the

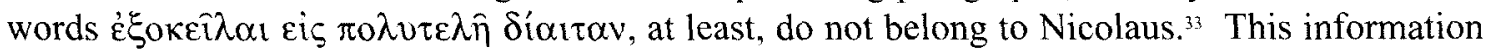
becomes very significant if we are aware that Athenaeus had quoted the same lines of Nicolaus at 6.274e-f. ${ }^{34}$ The earlier quotation is substantially identical, and we find once again the expression

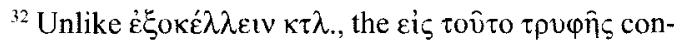

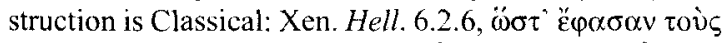

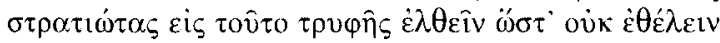

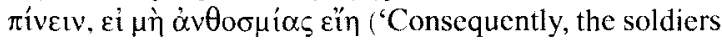
advanced so far into luxury that they refused to drink if the wine did not have a fine bouquet'). It is the high frequency of this expression in Athenaeus that is the basis of our argument. In addition, the same reasoning seems to apply to the many instances in which Athenaeus introduces a $\tau \rho \varphi \eta$ ́ example (or effects a transition between parts of a $\tau \rho u \varphi \eta$ example) with a correlative cxpression completed by a result clause (this time, without the

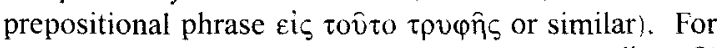
example, $12.526 \mathrm{~b}$ (of the Colophonians), oü $\omega \delta^{\prime}$

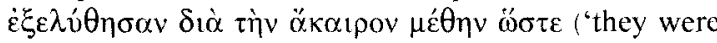
so undone by excessive alcohol that ...'); or $12.536 \mathrm{bc}$,

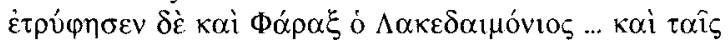

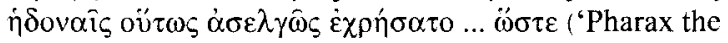
Lacedaemonian indulged in luxury and pursued his pleasure so wantonly that ...').

${ }^{33}$ It remains an open question the extent to which the sentence accurately reflects Nicolaus" meaning. It would be especially important to know whether it is Nicolaus himself who identifies Lucullus as the first to bring $\tau \rho v \varphi n$ to the Romans, since most of our ancient sources put this event much earlier. See Zecchini (1989) 119 n.231.

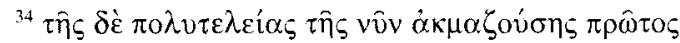

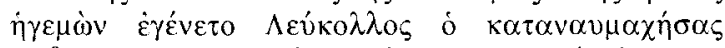

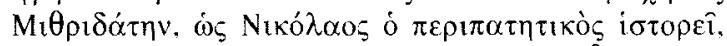

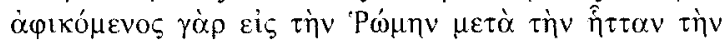

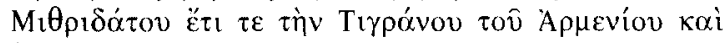

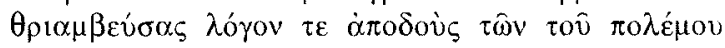

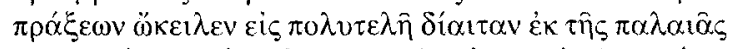

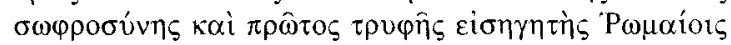

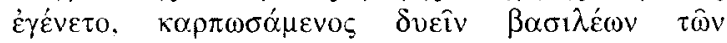
$\pi \rho o \varepsilon \iota \rho \eta \mu \varepsilon ́ v \omega v \pi \lambda o u ̂ t o v$. ("It was that Lucullus who defeated Mithridates who first introduced the extravagance that is now reaching its zenith. He, as Nicolaus the Peripatetic says, reaching Rome after the defeat of Mithridates and also that of Tigranes the Armenian and, celebrating his triumph and giving an account of his actions in the war, ran aground upon an extravagant way of life instead of his old moderation. Enjoying the wealth of the aforesaid two kings, he became the first to introduce luxury to the Romans.") 


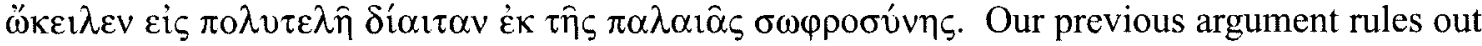
the likelihood that the phrase goes back to the original source, and it seems most implausible that Athenaeus, paraphrasing Nicolaus directly, would have added exactly the same material both times. ${ }^{35}$ Explanation must be sought elsewhere.

The most straightforward approach is to assume that these two passages reveal Athenaeus in the act of self-quotation. On this interpretation, Athenaeus, in the course of his reading, excerpted an interesting bit of Nicolaus into a 'notebook' ( $\left(j \pi^{\prime} \mu v \eta \mu \alpha\right)$, apparently marking the theme with a favourite introductory phrase ( $\left.\dot{\varepsilon} \xi_{\circ \kappa \kappa} \varepsilon \lambda \lambda \varepsilon \downarrow \nu \kappa \tau \lambda\right) .{ }^{36}$ Later, when composing the Deipnosophistae, Athenaeus used these notes where appropriate, drawing twice from this same entry to give us our doublet.

This view is a plausible way of analysing the evidence of Athenaeus' own text and may be correct. However, certain data external to this text must give us pause. Scholars have long noted similarities between many passages in Athenaeus and in the Varia Historia of Aelian. Detailed discussion of the problems involved in understanding the relationship between these two works need not detain us. On the other hand, several parallels between Aelian and Athenaeus are pertinent to the question at issue.

$V H 12.24$ concerns that familiar example of $\tau \rho v \varphi n$, Smindyrides:

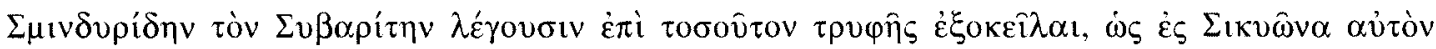

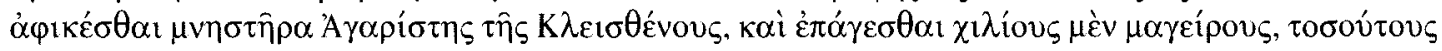

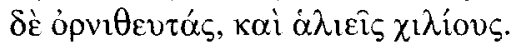

They say that Smindyrides the Sybarite ran aground on so much luxury that he came to Sicyon as a suitor of Agariste the daughter of Cleisthenes and brought a thousand cooks and the same number of fowlers and fishers.

While there is nothing particularly interesting about the content of the passage - we have seen the same details about the fishers and fowlers and cooks in Athenaeus, where Pelling suggests they come from 'general knowledge' - the phraseology of its introduction is quite striking. Aelian has

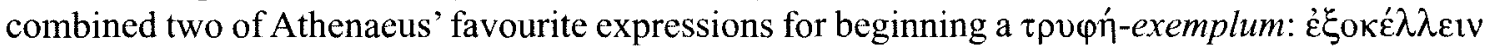

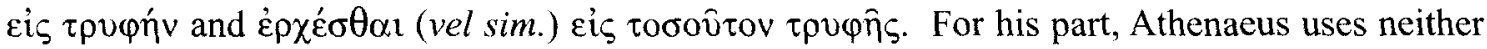
phrase in connection with Smindyrides, nor does he ever combine the two phrases so closely in any context. If, then, Aelian relies upon Athenaeus for this material, he shows a keen eye for the idiosyncrasies of his model, a virtue which few of Aelian's modern critics would admit. Moreover, Aelian repeats the combination in other passages:

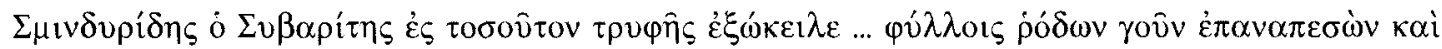

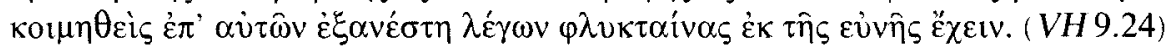

Smindyrides the Sybarite ran aground on so much luxury ... lying down on rose petals and sleeping on them, he got up saying that he had sores from the mattress.

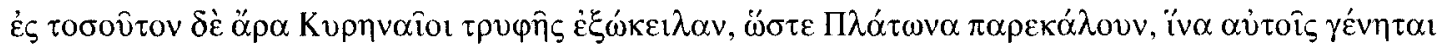
vouotétns. (VH 12.30)

\footnotetext{
${ }^{35}$ We cannot absolutely exclude the possibility that the words in question do go back to Nicolaus, since we have noted that the expression begins to become popular near the beginning of the Common Era. However, Nicolaus' would be the carliest attestation of this usage (to run aground on a subjective vice). Given Athenacus' apparent fondness for the phrase, it therefore seems best
}

not to multiply causes and to operate on the assumption that the formulation was not part of the original.

${ }^{36}$ Important works on the use of notebooks by ancient authors include Pelling (1979 and 1985) and Van der Stockt (1999), both on Plutarch. Jacob (2001) lxxivIxxxiii discusses 'rotoli di note di lettura' in Athenaeus' own day. 
The Cyreneans ran aground on so much luxury that they tried calling in Plato to become their lawgiver. Neither of these two instances of $\tau \rho v \varphi \eta$ appears in Athenaeus, at least as now extant; direct borrowing is therefore unlikely. Perhaps this evidence suggests that both Athenaeus and Aelian were, at the very least, influenced by the diction of a common source. This source need not have been

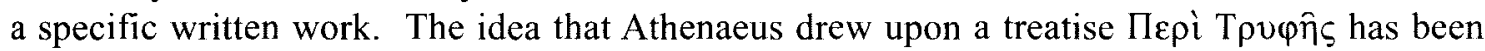
raised many times in the literature - and rejected just as often. ${ }^{37}$ The fons in question may rather have been once again 'general knowledge', assuming that the effects of $\tau \rho v \varphi \eta$ had become a wellworn topos in the schools, with its own characteristic turns-of-phrase in addition to standard examples. ${ }^{38}$

For the present, talk of an intermediary $\tau \rho \cup \varphi \eta$-tradition remains speculation, but if we are cor-

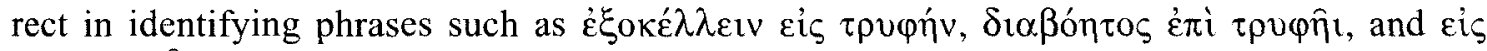
$\tau 0 \sigma 0 \hat{\tau} \tau o v \hat{\eta} \lambda \theta$ ov $\tau \rho \cup \varphi \hat{\eta} \zeta \dot{\omega} \zeta$ as introductory or transitional expressions that should not be attributed to the original named sources, then the question of Mittelquellen must eventually be reopened and this new complication dealt with in detail. Meanwhile, a cautious and conservative approach to the historical evidence preserved in Athenaeus must allow for the very real possibility that some parts of that evidence may have been affected by passing through one or more layers of transmission before reaching Athenaeus.

\section{THE LUXURY OF THE SYBARITES}

We may now turn to examine Athenaeus' testimony on Sybarite $\tau \rho \cup \varphi \eta$. The earliest prose author that Athenaeus cites on this matter is Aristotle. At $12.520 \mathrm{c}$ we read on the authority of Aristotle in his Constitution of the Sybarites (or of the Crotoniates?) that the Sybarite custom of training their horses to dance to the flute put them at a tactical disadvantage in their war with Croton. This passage presents no good evidence that Aristotle represented this incident as connected with $\tau \rho v \varphi \eta$.

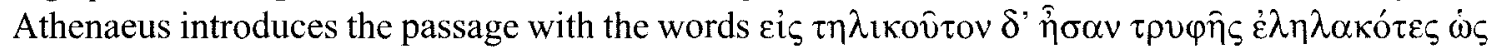

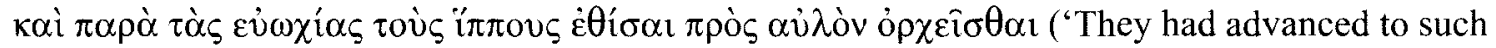
a degree of luxury that their horses were accustomed to dance to the flute even at their feasts'). As argued above, in prudence we must assume that this sentence is not Aristotle's. In addition, Athenaeus himself notes that nearly the same story is told of the Cardians, and as Athenaeus relates the Cardian episode (following Charon of Lampsacus), $\tau \rho \vartheta \varphi \eta$ seems to play no part. It is consistent with this evidence to judge that Aristotle may have discussed the dancing horses of Sybaris as a curiosity, not as symptomatic of the city's decadence.

$12.523 \mathrm{c}$ also names Aristotle in connection with Sybarite $\tau \rho v \varphi \eta$ :

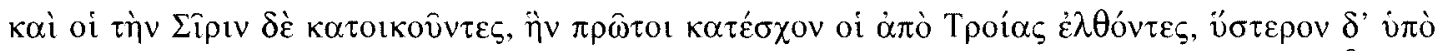

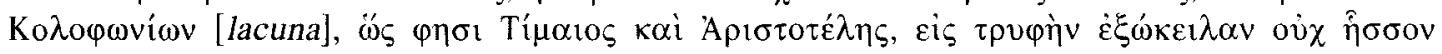
$\Sigma v \beta \alpha \rho \imath \tau \hat{\omega} v$.

And those occupying Siris - first those coming from Troy possessed it, but later by the Colophonians [lacuna], as Timaeus and Aristotle say - ran aground upon luxury no less than the Sybarites.

37 The supposed existence of an intermediate source for Book 12 is based ultimately on the words found in the margin of Codex Venetus Martianus 447 at 12.518d:

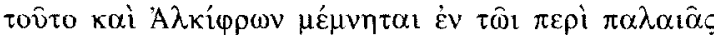

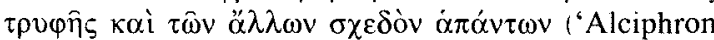
mentioned this and nearly all the same things in his book
On Ancient Luxury'). For a discussion of this Alciphron, see Zecchini (1989) 178 with n. 150

${ }^{38}$ Nyikos (1941) 9: plerumque nihil aliud concludi potest nisi eas res, quae apud Athenaeum, Aelianum. ceteros narrantur, temporibus illis ubique - et Athenis et Romae et Alexandriae - notas atque pervulgatas fuisse. 
Athenaeus goes on to describe the beautiful clothing of the people of Siris. Once again, mention of $\tau \rho \cup \varphi \eta$ - whether that of Siris or of Sybaris - is a later addition by Athenaeus, who is citing the two probably as evidence merely for the Colophonian settlement at Siris. ${ }^{39}$

The third passage in which Aristotle is quoted $v i s-\grave{a}$-vis Sybaris is of particular interest, since this time the original is still extant. $12.541 \mathrm{a}-\mathrm{b}$ reproduces Mirabilium auscultationes 96.838a 15-26, where we are told of the fabulous i $\mu \alpha$ น (or Alcimenes). ${ }^{40}$ The garment was remarkably extravagant, embroidered with images of, inter alia: Zeus and other gods; Susa, the Persian capital; Sybaris; and Alcisthenes himself. It was dedicated at the Lacinium of Hera. Dionysius the Elder later bought it from the Carthaginians for 120 talents. Athenaeus quotes from his authority verbatim with great accuracy. Nonetheless, he subtly mani-pulates the original to suit his own argument, through both addition and omission. As transmitted directly, the text of the Mirabilium passage begins:

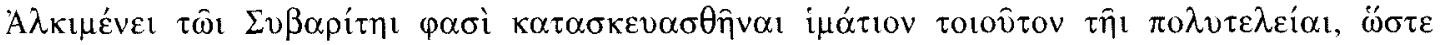

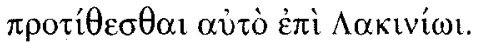

They say that such an expensive mantle was prepared for Alcimenes the Sybarite that he dedicated it at the Lacinium.

Compare Athenaeus' introduction to the anecdote:

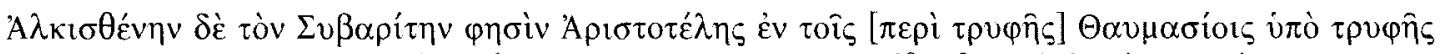

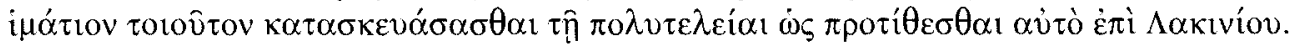

Aristotle says in The Wonders that Alcisthenes the Sybarite from decadence had prepared such an expensive mantle that he dedicated it at the Lacinium.

In Mirabilium the story of Alcisthenes has no context; the marvel as presented has no moral dimension, explicit or implied. For Athenaeus this will not do. The authorities he cites must support his position. ${ }^{41}$ He adds the crucial words $\dot{u} \pi \dot{\mathrm{o}} \tau \rho \nu \varphi \hat{\eta} \varsigma$, and Alcisthenes becomes another example of the immorality of Sybaris. ${ }^{42}$

Similarly, because he values the testimony of Aristotle so highly, he neglects to inform his reader that the philosopher (as he thinks) is here giving hearsay evidence: Mirabilium presents its account as a report drawn from unspecified sources $(\varphi \alpha \sigma i)$. Athenaeus removes this inconvenient reference and represents the decadence of Alcisthenes as Aristotle's own opinion ( $\varphi$ noiv Apı $\tau \tau \tau \tau \dot{\varepsilon} \lambda \eta \varsigma) .{ }^{43}$ Thus, although as a spurious work Mirabilium can tell us nothing about traditions

${ }^{39}$ It is also possible that the information about the clothing came from Timaeus, who seems to have had an ethnographical interest in the way peoples dressed.

${ }^{40}$ Mirabilium auscultationes is, of course, not a work of Aristotle. Its loosely organized composite structure may be the result of contributions by several compilers. The various strata of which it consists are difficult to date with accuracy, but we need not be concerned here with such details. From our point of view it is sufficient that Athenaeus treats it as genuine.

41 Interestingly, Flashar (1981) 115, following Geffcken (1892) 96, confidently identifies the source of this story: 'Timaios hier sicher zu greifen ist'. The basis of this identification is Timaeus' notorious fascination for

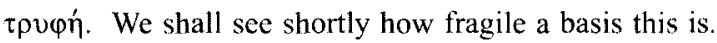
Athenaeus does give us the information $(12.541 \mathrm{~b})$ that the garment was mentioned by Polemon in the work entitled $\Pi \varepsilon \rho i \tau \hat{\omega} v \dot{\varepsilon} v \mathrm{~K} \alpha \rho \chi \eta \delta \delta^{\prime} 1$ Пદ́ $\pi \lambda \omega v$; this fact would give us a terminus ante (c. $190 \mathrm{BC}$ ).

${ }^{42}$ It is worth pointing out that Athenaeus' interpretation, which makes the mantle of Alcisthenes a symbol of Sybarite luxury, is probably correct. The story seems to belong to the same tradition as other exaggerated examples of Sybarite $\tau \rho v \varphi n$, such as those surrounding Smindyrides. Thus, in order to adapt Mir $96.838 \mathrm{a} 15-26$ to his own argument, Athenaeus coincidentally restored the moral context which the author of Mirabilium had removed, since he was interested only in the wonder itself. We think Athenaeus would have appreciated the irony.

${ }^{43}$ Despite the fact that he includes in his quotation a second $\varphi \alpha \sigma i$ which occurs a few lines later (in connection with the mantle's purchase by Dionysius). We may take 
of Sybarite $\tau \rho \cup \varphi \eta$ available to Aristotle, it does offer us a manifest case of that aspect of Athenaeus' method of citation which calls for the greatest circumspection in the modern historian: his painstaking accuracy in verbatim quotation undercut by slight but significant alteration.

In any case, Athenaeus produces no Aristotelian testimony bearing clearly on the issue of Sybarite luxury and most certainly no evidence that Aristotle was aware of a link between $\tau \rho v \varphi \eta^{\prime}$ and $\tilde{\beta} \beta \rho \iota \varsigma$ at Sybaris.

Athenaeus cites Heracleides Ponticus twice on the subject of Sybaris. At $12.521 \mathrm{e}-\mathrm{f}$, we are informed that immorality indeed led to the fall of that city: after the overthrow of the tyrant Telys, the members of his faction were slain on the altars. After that, the statue of Hera turned her back on the city, and a fountain of blood issued from her temple. For this reason, and for trying to diminish the Olympic games by setting up a rival contest with richer prizes $(\ddot{\alpha} \theta \lambda \omega v \dot{v} \pi \varepsilon \rho \beta \circ \lambda \hat{\eta} 1)$, the

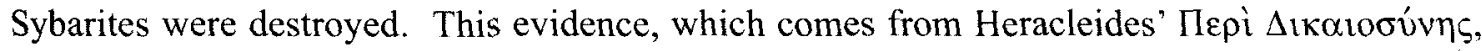
shows no explicit sign of $\tau \rho v \varphi \eta$. To be sure, both the murders and the attempt to subvert the Olympics are acts that fall under the heading of üßpıs. However, as we shall discuss below, when dealing with a fourth-century author, we have no warrant to assume a causal relationship between

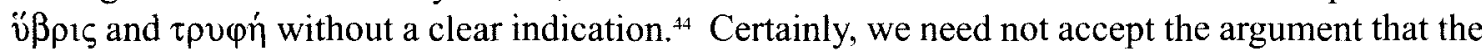
transmission of historical 'facts' such as those presented here were motivated by the desire of Sybaris' enemies to justify its destruction. ${ }^{45}$ According to Athenaeus, Heracleides offers (12.523f) in Book 2 of On Justice a parallel explanation of the destruction of Miletus by the Persians: $\delta i \dot{\alpha}$

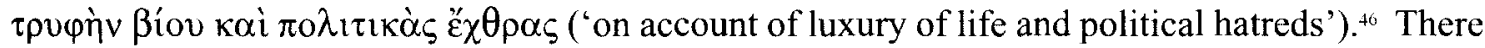
can be no question of the Persians feeling a need to justify in this manner what they did to Miletus. We may suggest that whatever circumstances led to the generation of the story of murder and divine retribution at Miletus would have sufficed in the case of Sybaris as well.4?

The second pertinent reference to Heracleides is to his On Pleasure:

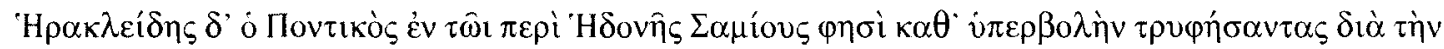

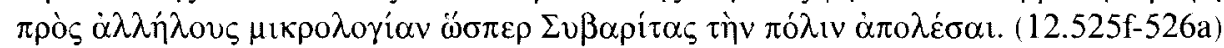

Heracleides Ponticus says in his On Pleasure that the Samians, luxuriating excessively, on account of their pettiness towards each other, like the Sybarites, lost their city.

Although this passage seems straighforward, it is quite difficult to understand precisely. In the first place, Athenaeus gives no further details, so we cannot begin to judge the accuracy of his characterization of this source. We know enough of Athenaeus' method to suspect that some part of the sentence is interpretation that may be inconsistent with Heracleides' evidence. It is quite possible, for example, that $\dddot{\sigma} \sigma \pi \varepsilon \rho \Sigma v \beta \alpha \rho i ́ \tau \alpha \varsigma$ is a comparison added by Athenaeus, for whom the parallel was obvious, and that Heracleides drew no analogy between Samos and Sybaris. Secondly, it is unclear how much of the predicate these words of comparison should be taken to qualify. At a min-

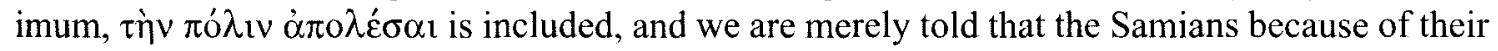

this opportunity to emphasize that we intend no facile criticism of Athenaeus. As Jacob (2001) xcvi indicates, Athenaeus may have meant such citations as playful irony, knowing that his readers might be familiar with many of the original texts. Our admonitions are rather aimed at modern historians who are ready to accept Athenaeus' evidence without the heightened level of caution for which we argue.

${ }^{44}$ Fisher (1992), esp. 111-17, finds no causal relationship outside Athenaeus and the authors cited by him.
${ }^{45}$ Discussed with clarity by Ampolo (1993) 217-22.

${ }^{46}$ The subsequent details make clear that $\pi 0 \lambda_{1} \tau \mathrm{i} \alpha \dot{\alpha} \zeta$ $\check{\varepsilon}_{\chi} \chi \rho \rho \alpha \zeta$ are manifestations of $u ̈ \beta \rho 1 \zeta$. These words, part of Athenaeus' introduction of this evidence, are probably to be attributed to Athenaeus or his immediate source rather than to Heracleides.

${ }^{47}$ Gorman (2001) 102-7 argues that the story of violence at Miletus was based on the text of a prophecy that came - probably erroneously - to be associated with the Ionian city. 
behaviour lost their city, just as did the Sybarites because of theirs. ${ }^{48}$ In view of these uncertainties, it is perhaps best to set this passage aside as more informative of Heracleides on the Samians than the Sybarites.

To Theophrastus is attributed one fragment on Sybaris. In his On Pleasure, we are told $(12.511 \mathrm{c})$, Theophrastus compared the life of Aristeides to those of Smindyrides and Sardanapallus:

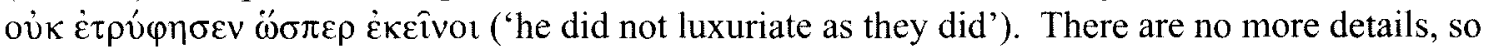
caution again leads us to hesitate to accept Athenaeus' word that Theophrastus viewed Smindyrides' lifestyle as immoral.

At $6.273 \mathrm{c}$ Athenaeus cites Chamaeleon of Heraclea Pontica, and it will be convenient to discuss this passage here, since Athenaeus notes that the work On Pleasure to which he refers is sometimes attributed to Theophrastus. The subject is once more Smindyrides, in a passage we have discussed above in the context of Pelling's analysis of Athenaeus' method. Athenaeus reports that Smindyrides, motivated $\dot{v} \pi \hat{o} \chi \lambda_{1} \delta \hat{\eta} \zeta \kappa \alpha i \tau \rho v \varphi \hat{\eta} \varsigma$, took a thousand servants when he went to compete for the hand of Agariste of Sicyon. Pelling astutely observes that this anecdote is unattributed, while Chamaeleon (or Theophrastus) is given responsibility only for the information that for 20 years Smindyrides saw neither sunrise nor sunset. Significantly, Smindyrides' sleeping habits

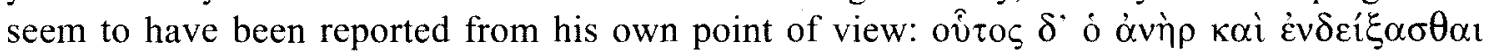

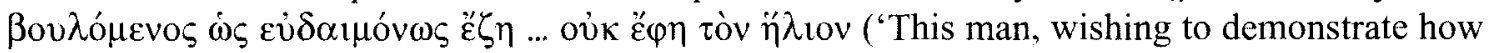
happily he lived, denied that he had seen the sun ...'). Thus, for Chamaeleon, Smindyrides was a self-professed proponent of hedonism, and Smindyrides' original claim (wherever Chamaeleon may have found it recorded) was no admission of immoral behaviour. ${ }^{+19}$ Nor do we have any reason to assume that Chamaeleon himself characterized it as an example of the vice of $\tau \rho v \varphi \eta .^{50}$ This passage is therefore not evidence for the existence of a tradition of Sybarite decadence in the fourth century.

Timaeus of Tauromenium is Athenaeus' favourite source on Sybaris. The Deipnosophistae includes at least seven pertinent fragments of that author. The first occurs in the epitome of $1.34 \mathrm{c}$, where we are told that the presence of cabbage weakens the effects of wine: $\delta$ io k $\alpha$ i $\Sigma v \beta \alpha \rho i \tau \alpha$,

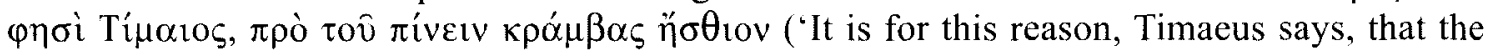
Sybarites ate cabbages before drinking'). Some have seen here an allusion to $\tau \rho v \varphi \eta^{\prime}$, of which drunkenness is certainly a part. We merely note that it is precisely in reporting the motivation ex-

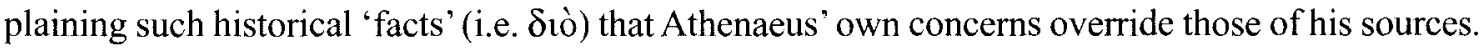
The relationship between the Sybarites' fondness for cabbage and their putative love of wine may be an observation of Athenaeus or of his epitomizer, not Timaeus.

The next passage is more to the point. According to Athenaeus 12.518d, Timaeus knew a joke about Sybarite laziness: ${ }^{51}$

\footnotetext{
${ }^{48}$ If the comparison includes $\delta i \dot{\alpha} \tau \dot{\eta} v \pi \rho \dot{s} \varsigma \dot{\alpha} \lambda \lambda \hat{\eta} \lambda$ ov

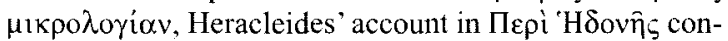

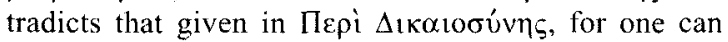

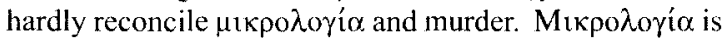
used consistently for petty reasoning, splitting hairs, or even stinginess: e.g. Isoc. 13.8, 15.262; Plato, Theat. 175a7, Hp. mai. 304b4, Resp. 486a5, 558b1, Leg. 746e4; Arist. Metaph. 995a10. At a stretch, it can mean 'to belittle', as at Isoc. 15.2, but nothing more momentous is signified. Such a contradiction is of course possible, given the different focus of the two works.

${ }^{49}$ Compare Athenaeus $12.512 \mathrm{a}$, where we are told that Heracleides Ponticus included in his On Pleasure a de-

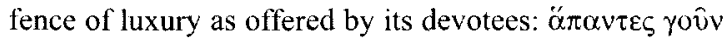

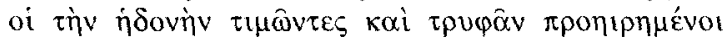

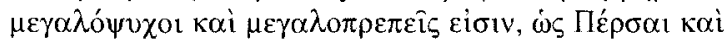

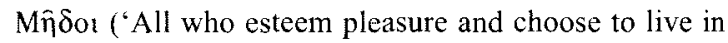
luxury are lordly and magnificent, like the Persians and Medes').

50 The words which close the discussion of Smindyrides - ở

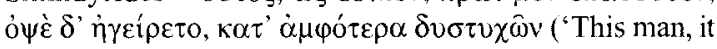
seems, went to bed early and got up late, unfortunate on both counts') - are to be taken as Athenaeus' rather than Chamaeleon's, since their point seems to be a contrast with the next example, Hestiaeus Ponticus, who "properly boasted' ( $\kappa \alpha \lambda \hat{\omega} \varsigma \dot{\varepsilon} \kappa \alpha \cup \chi \hat{\alpha} \tau 0$ ) that he had not seen the sun come up or go down because of his constant dedication to his studies.

${ }^{5 !}$ The discussion of Sybarite $\tau \rho \nu \varphi \eta$ begins a few lines before Timaeus is named. In this section Athenaeus relates that the Sybarites shackled their bath slaves to keep them 


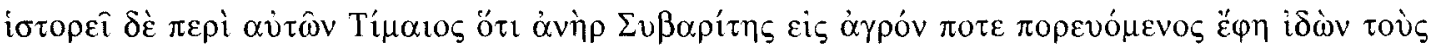

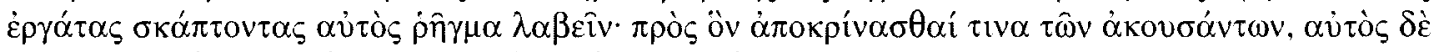

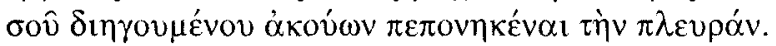

Concerning these people, Timaeus relates that a man of Sybaris said that, when on the way to the country he caught sight of some workmen digging, he ruptured himself. To which one of his audience responded: 'I myself hurt a rib just listening to you.'

This evidence shows that Timaeus was aware of an association between Sybaris and $\tau \rho v \varphi \eta$, since extreme indolence is one of the manifestations of that vice. On the other hand, this story is simply a joke, and we need assume neither a historiographically motivated origin nor that it is part of a systematic argument for $\tau \rho v \varphi \eta$ as a leading factor in the destruction of Sybaris.

However, to complicate matters, the passage just quoted is immediately followed by two more anecdotes. Both concern visits by Sybarites to cities that symbolized moderation of lifestyle. In the first, a group of Sybarites at Croton sees an athlete softening his own ground in the palaestra and the visitors wonder aloud that the Crotoniates have no slaves to do such a task. In the second story, the location is Sparta, where a Sybarite is invited to a common mess to eat the food of the locals. It is no strange thing, he exclaims, that the Spartans act with such courage: the worst coward would prefer to die rather than to live such a life.

These stories may be seen as evidence of historiographical dimensions of $\tau \rho \nu \varphi \eta$, since the contrast between Sybarite luxury and simpler life at Croton and Sparta may point to a theory of historical causation: $\tau \rho \cup \varphi \eta$ brought Sybaris to ruin, while moderation made the Crotoniates and Spartans powerful. Of course, for such an interpretation to be persuasive, one must establish that these examples appeared in the text of some historian. Unfortunately, we cannot be confident that they come from Timaeus. In addition to Pelling's general caution that Athenaeus sometimes brings foreign material under the aegis of a named authority, there are more particular reasons for scepticism. One such reason is the repetition at $4.138 \mathrm{c}$ of the story of the Sybarite at Sparta. Here Athenaeus gives the tale a non-specific attribution ( $\varphi \alpha \sigma i$ $\delta \varepsilon \tau^{\prime} \tau(v \varepsilon \varsigma$ ) which we are perhaps justified in taking as a reference to general knowledge. ${ }^{52}$ If the Sparta anecdote may be Athenaeus' own contribution, it is economical to posit the same source for the Croton story, since the two make the same point, putting Sybarite sloth in the context of more traditional Greek mores. ${ }^{53}$ The story of the ruptured Sybarite is not parallel. ${ }^{54}$ Thus, in order to put Timaeus' evidence about Sybaris on the most secure footing, we should mark the end of this fragment at the close of the rupture joke.

from bringing the hot water too quickly and scalding their masters; that smiths and carpenters were forbidden by law from working in the city, since they were too noisy; that it was not even permitted to raise roosters in Sybaris. We have seen that Pelling urges caution in such cases: just because Timaeus is the first authority mentioned in this context, we may not assume that Athenaeus is attributing all the material to that author. By contrast, Zecchini (1989) in his discussion of this passage does not even seem to be aware of complications such as those laid out by Pelling: 'per l'esattezza il testo di Timeo comincia con la formula

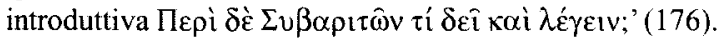
In other words, Zecchini accepts the anecdotes preceding the citation of Timaeus as the historian's own. Unfortunately, Zecchini offers no arguments to explain his confidence.

${ }^{52}$ As Pelling does in connection with the Smindyrides passage.
${ }^{53}$ The placement of the Croton story immediately after the rupture story may have been suggested to Athenaeus by the occurrence in both of the verb $\sigma \kappa \alpha \dot{\alpha} \tau \omega$ ('dig').

${ }^{54}$ It is difficult to know what to make of the fact that Diodorus Siculus apparently related the Sparta story and the rupture story together $(8.18)$, perhaps in close proximity to the tradition that the Sybarites were especially friendly with the Ionians and the Etruscans (8.18), a tradition that Athenaeus explicitly ties to Timaeus. Some scholars (e.g. de Sensi Sestito (1988) 405-6; Bugno (1999) 7-8) take this pattern of collocation as evidence of Timaean origin. We merely note that there is some indication that Diodorus knew of an intermediate moralizing $\tau \rho v \varphi n$-tradition such as that upon which Athenaeus seems to have relied. It is likely that the Sybaris material from Diodorus 8 passed through such a stage. For example, introducing the relationship between Sybaris and Ionia is the

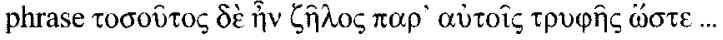


Another fragment occurs in close succession. At $12.518 \mathrm{f}$ Athenaeus reports that, $\ddot{\varsigma} \varphi \eta \sigma \mathrm{\sigma}$ o Tíu $\alpha$ los, the Sybarites were accustomed to keep dwarfs and small Maltese dogs. ${ }^{55}$ As usual, the

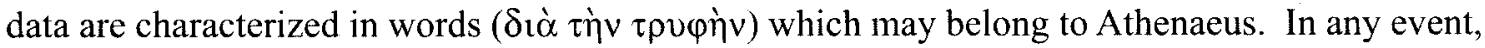
no historiographical connection to 0 $\beta p ı$ or to the ruin of the city is evident.

Some interpreters maintain that $12.522 \mathrm{a}$ proves that Timaeus understood $\tau \rho \nu \varphi \eta$ as a morally corrosive contagion that passed by contact from one city to another:

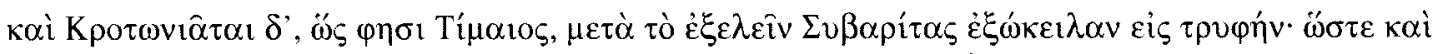

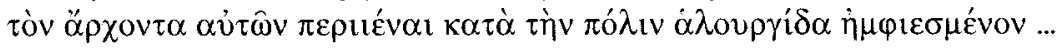

The Crotoniates too, as Timaeus relates, after the capture of the Sybarites, ran aground upon luxury, so that their ruler went around through the city wearing purple ...

By now, it would be belabouring the point unduly if we were to do more than indicate that the words introducing this passage cannot be assigned to Timaeus. We are left with information on the dress of the Crotoniate leader that may have been merely ethnographical in import. ${ }^{56}$

Timaeus' testimony at $12.523 \mathrm{c}$ has been discussed in connection with Aristotle. Likewise we have seen that Pelling's arguments make short work of the assumption that Timaeus is responsible for the information at $12.54 \mathrm{lb}$-c that Smindyrides went courting "with a thousand cooks and fowlers'.

The final fragment of Timaeus which pertains to Sybaris begins at $12.519 \mathrm{~b}-\mathrm{c}$. We have taken it up out of its order in the text of Athenaeus because it has been the most important source on Sybarite $\tau \rho \varphi \varphi \eta$ in the scholarship. The passage begins with Athenaeus noting that the Sybarites wore i $\mu \alpha \dot{\alpha} \tau \alpha$ made from Milesian wool. The wool trade, it seems, was the basis for the close relationship between the two cities:

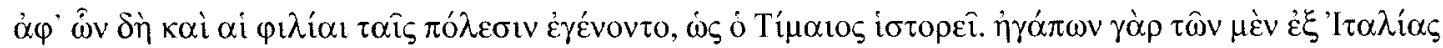

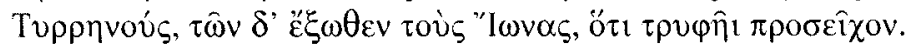

From this the cities became friends, as Timaeus relates, for of the people of Italy they became close to the Etruscans, and of outsiders to the Ionians, because they were devoted to luxury.

Attention to Athenaeus' habit of massaging all evidence to fit his argument must make us aware that it is not unlikely that the reference to $\tau \rho v \varphi \eta$ was not in Timaeus. We are left with a fact about Sybarite dress and the observation that friendship follows trade. So far, there is nothing that would make plausible a tradition in which $\tau \rho \cup \varphi \eta$ might justify the fall of Sybaris. ${ }^{5 ?}$

('Their zeal for luxury was so great that ...'). In our general remarks on Athenaeus' method we have argued that similar expressions belong to an intermediate source (of indeterminate kind) for the discussion of $\tau \rho u \varphi \eta n$ in the Deipnosophistae. Thus, collocation of similar material in Athenaeus and Diodorus may reflect the influence of an transmitting rather than original source.

${ }^{55}$ The material attributed to Timaeus is preceded by a sentence in which we are told about the extravagant dress of the Sybarite youth. Once again, the source may be general knowledge.

${ }^{56}$ The details of this passage, relating as they do to Croton, do not concern us. However, we note that recognition that $\dot{\varepsilon} \xi \hat{\omega} \kappa \varepsilon 1 \lambda \alpha \nu \varepsilon i \zeta \tau \rho \cup \varphi \eta v v$ is not of Timaean origin renders otiose Jacoby's suggestion that the alternate explanation offered here for the Crotoniate custom also goes back to Timaeus, who presented it for polemical reasons.
The introductory and concluding words of that alternative are germane to our discussion $(12.522 b-c)$ : oì $\delta \dot{\varepsilon}$ oủ $\delta i \grave{\alpha}$

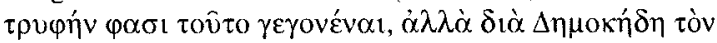

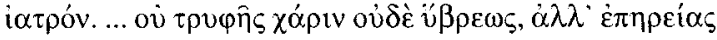

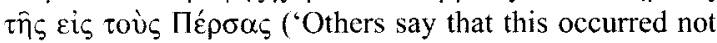
because of luxury, but because of Democedes the physician. ... not for the sake of luxury or of arrogance [sc. do they do this] but out of contempt for the Persians'). Just as the insinuation of motive (où $\delta \dot{\alpha} \tau \rho v \varphi \eta j v$ ) in the first part of the quotation is typical of Athenaeus' method, so also the

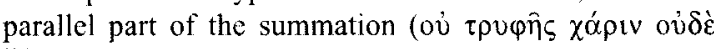
ú $\beta \rho \varepsilon \omega \varsigma)$ stems from Athenaeus or his proximate source. Thus, one cannot assume that the close connection made

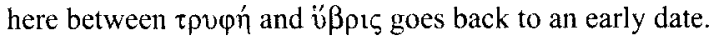

${ }^{57}$ We recognize that Milesian wool was well known for its softness. Diodorus Siculus knows of a tradition according to which the law of Zaleucus forbade men to wear 
On the other hand, the words just quoted are followed by a long series of examples that without doubt illustrate a serious decadence. To give just a few: wealthy Sybarites took three days for a one-day journey into the country; roads leading to the countryside were roofed over; they publicly crowned cooks who developed fine dishes. The sequence culminates with an oracle that they will prosper until they hold a man in greater honour than the gods. This prophecy is fulfilled, and the city is soon destroyed due to rivalry both among the Sybarites themselves and between Sybaris as a community and all the other cities - rivalry in pursuit of $\tau \rho v \varphi \eta$.

No case of $\tau \rho \cup \varphi \eta$ as a principle of historical causation could be clearer. However, Pelling's work has taught us that we cannot assume without further argument that all the examples collected here come from Timaeus. The content of the Timaeus fragments on Sybaris already examined tells against Timaean authorship of the material at $12.519 \mathrm{~b}-\mathrm{e}$. The facts that can be securely ascribed to Timaeus are these: the Sybarites were fond of cabbage, they kept dwarfs and Maltese dogs, they wore Milesian wool clothing, and they traded with Ionia and Etruria. Timaeus also relates the joke about the ruptured Sybarite. Such tame material is hardly consonant with the exaggerated and even fantastic data given here (e.g. that the Sybarites piped wine from vineyard to warehouse or that they were the first to invent the chamber-pot). Nor can we find in Jacoby's collection of Timaeus' fragments (FGrHist 566) any parallel for this kind of uncritical credulity outside the realm of the mythological, if we assume that Timaeus seriously presented these items as facts about Sybaris. ${ }^{s}$ Furthermore, in spite of the scholarly orthodoxy, the evidence that Timaeus was at all interested in $\tau \rho \nu \varphi \eta$ is extremely thin..$^{59}$ In view of these considerations, we conclude, as Pelling does in a similar case at $12.535 \mathrm{~b}-\mathrm{e}$, that the instances of $\tau \rho v \varphi \eta$ in this passage are 'a catch-all medley from general knowledge'.

The last two authors whom Athenaeus cites in regard to Sybaris can be dispatched quickly. At $12.521 \mathrm{c}$ Athenaeus quotes Phylarchus (d. after 220/219) on a severe sumptuary law at Syracuse. Syracusan moderation stands in contrast to Sybarite $\tau \rho v \varphi \eta^{\prime}$, for it was law in Sybaris that women must be invited to a feast with a year's notice, so that they might prepare their costumes. The

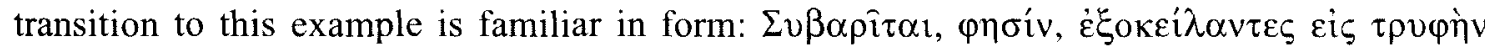

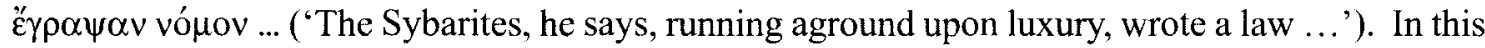
case the body of the quotation does support the interpretation that Athenaeus has given Phylarchus. The supposed law must be an instance of the $\tau \rho v \varphi \eta$ of Sybaris. Nevertheless, this passage need not attest to the existence of a principle of historical causation. Rather, its origin is not far to seek: the Hellenistic interest in sumptuary legislation which led to the 'discovery' of the Syracusan case would suffice to create the Sybarite vó $\mathrm{o}_{\varsigma}$ as a foil. ${ }^{61}$ Thus, we can accept this passage as evidence that by 220 BC Sybaris had become a symbol of $\tau \rho v \varphi \eta$. It is not, however, proof of $\tau \rho v \varphi \eta$ as agent of historical change.

A more likely possibility for that proof follows a few lines later, when we read that the Sybarites eventually turned to ü $\beta \rho ı$. They slaughtered ambassadors from Croton on the altars, provoking the anger of Hera and their own destruction (12.521d). Unfortunately, interpretation is not easy.

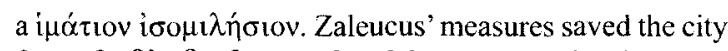
from $\tau \hat{\eta} \varsigma \beta \lambda \alpha \beta \varepsilon \rho \hat{\alpha} \varsigma \tau \rho v \varphi \hat{n} \varsigma$. Of course, scholars have noticed that the law is not Archaic, and is probably not older than the fourth century $\mathrm{BC}$; $c f$. Bernhardt (2003) 31-2 with notes.

${ }^{58}$ It is impossible to rule out that Timaeus related them as funny stories about the Sybarites. After all, he did tell the rupture joke, and there is a tradition of Sybarite jokes

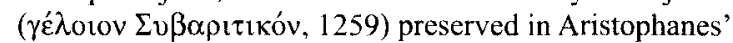
Wasps, although these gags are not particularly linked to luxury. At 1427-31, Philocleon relates that an $\alpha v i \eta$

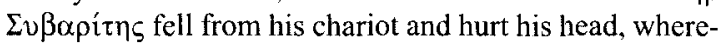
upon a friend told him to stick to the business he knew. A few lines later (1435-40), the subject is 'a woman of Sybaris' who, breaking a jar ('́xîvo $)$, passed a suitable

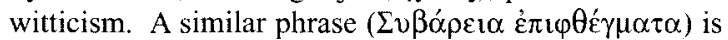
attributed to the fifth-century Sicilian comic, Epicharmus (Suda $\sum \hat{\gamma} \gamma \mu \alpha$ 1271). At any rate, in our case the passage would not be evidence that Timaeus recognized as a historical force the evolution from $\tau \rho v \varphi \eta$ to $\ddot{u} \beta \rho 1 \varsigma$ to $\dot{\alpha} \pi \hat{\omega} \lambda \varepsilon \dot{\varepsilon} \alpha$.

${ }^{59}$ See below, $n .81$

${ }^{60}$ Pelling (2000) 176.

${ }^{61}$ On the question 'Sind alle diese Gesetze unecht und Phantasieprodukte griechischer Moralisten?', see Bernhardt (2003) 248-54. 
We cannot overlook the possibility that this passage does not come from Phylarchus, since he is not named in the immediate context. In addition, transition to this passage is effected by the

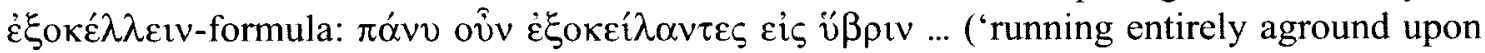
hybris ...'). This phrase usually occurs at the beginning of a citation and may therefore indicate a change of source. On the other hand, since, when introductory, the authority's name is normally mentioned, $\dot{\varepsilon} \xi_{0 \kappa} \dot{\varepsilon} \lambda \lambda \varepsilon \imath v \kappa \tau \lambda$. may well be resumptive in this instance. ${ }^{62}$ In sum, Phylarchus knew of Sybaris as a centre of $\tau \rho \cup \varphi \eta$. He may possibly have related the fall of Sybaris in terms of ú $\beta \rho \imath \varsigma$ and divine justice (giving essentially the same story as that already told in Heracleides). But the only connection between $\tau \rho v \varphi \eta$ and $u^{\prime} \beta \rho ı$ clearly is made in the words of Athenaeus or his immediate source. We cannot know whether Athenaeus is once more distorting the content of the original.

The final fragment touching on Sybaris is from Polybius. At 12.528a-b Athenaeus tells how the decadence of the Capuans led them to call in Hannibal. In $\tau \rho v \varphi \eta$ they excelled even Sybaris:

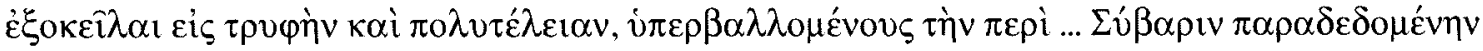

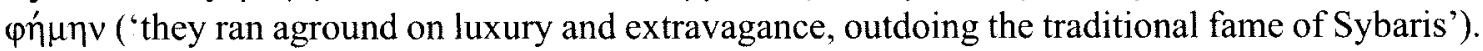
Given the presence of the $\dot{\varepsilon} \xi$ ok $\dot{\varepsilon} \lambda \lambda \varepsilon \downarrow v$-formula, it is legitimate to suggest that the reference to $\tau \rho \nu \varphi n^{\prime}$ and the comparison with Sybaris is not Polybian, although Polybius is certainly concerned with excess. ${ }^{63}$ The passage adds nothing to our explicit evidence on that city.

\section{CATASTROPHIC LUXURY}

Such is Athenaeus' evidence on Sybarite $\tau \rho v \varphi \eta$. We have made it clear that we think it of little value. One may object that we have treated Athenaeus unfairly: though it is clearly possible $a$

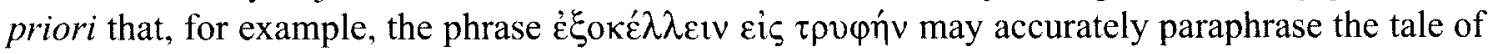
a community that fell into ruin because of luxury - with Sybaris as a prominent example - we have not allowed that interpretation. Our scepticism is considered. Although it is a commonplace that the idea of excessive luxury leading to personal and political destruction was a widespread Greek view, our examination of the evidence indicates that its importance has been much exaggerated.

There is no place here for a detailed treatment of the subject. We shall limit ourselves to a discussion of a few passages advanced by the two most comprehensive studies of the topic, Passerini (1934) and Bernhardt (2003), ${ }^{64}$ as the best proof of the historiographical significance of the idea of ruinous $\tau \rho v \varphi \eta^{65}$

\footnotetext{
62 If it is resumptive, we may assume that the intervening material (on certain patent laws and tax exemptions) is not from Phylarchus.

${ }^{63}$ Though Zecchini (1989) 90-1, followed by Walbank (2000) 162, believes this quotation to be taken directly from Polybius, few passages in Athenaeus can show so clearly the signs of manipulation: in addition to the $\dot{\varepsilon} \xi_{\circ} \sigma \varepsilon \dot{\varepsilon} \lambda \lambda \varepsilon t v$-formula, we find here the commonplace that

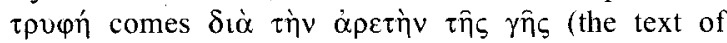
Diodorus alone offers parallels at 3.42.2, 5.10.2, and

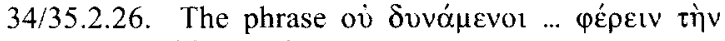

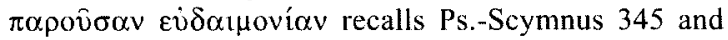
Diodorus 10.23. Even the subsequent contrast with the virtue of the Petelians has a now familiar appearance:

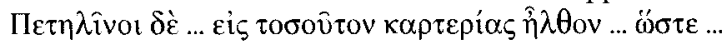
('the Petelians ... reached such a state of endurance ... that ...'). We suspect that this phraseology is the mark of transmission through a moralist or rhetorical tradition, but a detailed exploration must await another opportunity. In any case, it may not be an exaggeration to say that all
}

we can confidently ascribe to Polybius is the story that the Capuans called in Hannibal and the Petelians resisted him.

${ }^{64}$ Cozzoli (1980), Lombardo (1983) and Nenci (1983) also examine historiographical aspects of luxury at some length, but present no important evidence not dealt with by Passerini and Bernhardt.

${ }^{65}$ The word $\dot{\alpha \beta \rho o ́} \varsigma$ 'delicate, luxurious' and its $\operatorname{cog}$ nates first appear at the end of the seventh century BC. Throughout the Archaic period it was usually a positive

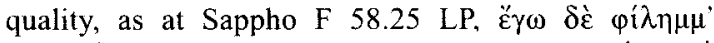

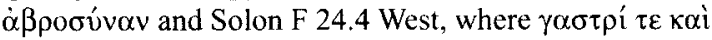

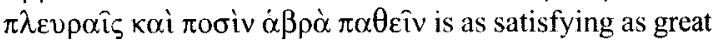
riches. This positive view of luxury seems to have prevailed well into the fifth century. The last decades of the 400 s saw an important shift with the appearance of the word $\tau \rho v \varphi \eta$, which by the fourth century was almost always negative in connotation. We are not here interested in the development of the idea of luxury as a vice, but only its use as historical explanation. 
We may stipulate at the outset that by the end of the fifth century there existed clear examples of peoples thought to have been weakened politically by a luxurious lifestyle. Herodotus, of course, already knew a tradition according to which Croesus advised Cyrus to raise the children

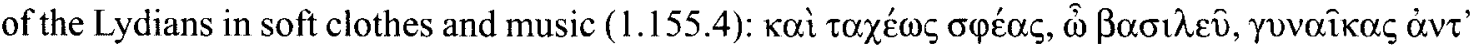

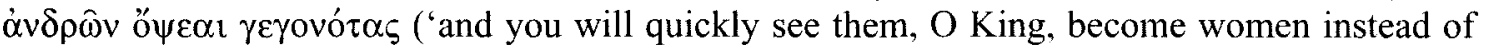
men'). In the same vein, Euripides depicts the Phrygians as weak in war (Or. 1483-5). Later, the list is expanded by Isocrates to include the Persians themselves, oì $\varsigma$ vं $\varepsilon \varepsilon \lambda \eta \dot{\eta} \varphi \alpha \mu \varepsilon v \mu \alpha \lambda \alpha \kappa o$ $\varsigma$

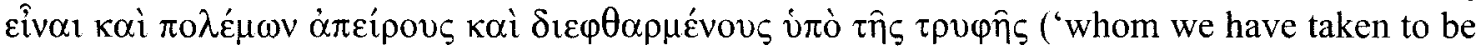
soft and ignorant of war and ruined by luxury', 5.124).

On the other hand, neither Passerini nor Bernhardt is able to offer good evidence that the idea of pernicious luxury had a more general application in the Classical and early Hellenistic periods; ${ }^{67}$ certainly they cannot make a persuasive case that it was a recognized principle of historical causation. For example, Theopompus of Chios is advanced as especially avid in pursuit of the effects of $\tau \rho v \varphi \eta{ }^{6,8}$ yet most of the numerous fragments of this author cited by Passerini fail to connect $\tau \rho \cup \varphi \eta$ with ruin in a significant way. ${ }^{69}$ Even where the fragment mentions both the luxury and the destruction of the subject, the relationship between the two remains dubious. F 114 (=) Athenaeus $12.531 \mathrm{a}-\mathrm{d}$ ) tells of the rivalry in $\tau \rho \nu \varphi \eta$ of Straton, king of Sidon, and Nicocles, the ruler of Cypriot Salamis. After detailing the emulous hedonism of the two, the passage ends by noting their deaths:

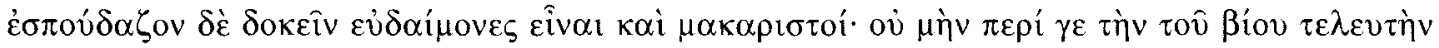

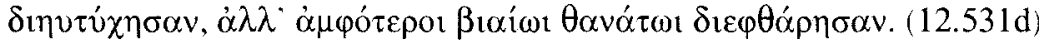

They sought earnestly to seem happy and prosperous, but their good luck did not extend to their lives' end; both died a violent death.

From the wording of this final sentence we might suspect that the moral pointed here is not the corrosive effects of luxury, but the familiar adage 'count no man happy before he dies' ${ }^{70}$ That this is the correct interpretation is confirmed by the immediate context in which Athenaeus quotes the passage. Before this, we are treated to a poem of Phoenix of Colophon, who purports to give the epitaph of King Ninus of Assyria, famous for his luxury. Ninus truly possessed, it seems, only the pleasures he experienced in life. Death came suddenly and violently, and his riches did not protect him. Ninus' words show no hint of regret towards his life of $\tau \rho v \varphi \eta$, only recognition that even such

${ }_{66}$ Plato, at Laws 694c-695e, explains how an education corrupted by $\tau \rho u \varphi n$ caused Cambyses and Xerxes to be much lesser men than their fathers and subsequent generations of Great Kings to be $\mu \varepsilon \dot{\gamma} \gamma \varsigma$ in name rather than in fact. Similarly, Republic $8.566 \mathrm{~b}-\mathrm{c}$ considers the penchant

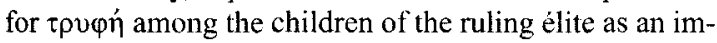
portant factor in the breakdown of oligarchies.

${ }^{67}$ Bernhardt (2003) 118-19 offers the historiography of Sparta as another example; the defeat of the Lacedaemonians at Leuctra was seen as a result of a turning away from the laws of Lycurgus. However, the only two passages Bern-

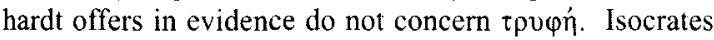
8.102-3 lays the blame for Spartan degeneracy not on luxury but on $\dot{\varepsilon} \xi o v \sigma i \alpha$, their ability to do whatever they liked. Likewise, the Constitution of the Lacedaemonians ascribed to Xenophon speaks of the corrupting influence of greed and the desire for gold. Greed is not the same thing as $\tau \rho \nu \varphi \eta$.

${ }^{68}$ Passerini (1934) 45; Flower (1994) 166 identifies 'Theopompus' interest in luxury ( $\tau \rho \varphi \varphi \eta)$ as an explanation for historical change'.
${ }^{69}$ In F 31 (Cotys), F 36 (early Italians), F 39 (Illyrians), F 49 (Thessalians), F 121 (Rhodian oligarchs), F 132 (Umbrians), F 134 (Dionysius), F 139 (Chalcidians), F 185 (Apollocrates), FF 187-8 (Niseus), F 204 (Etruscans), F 227 (Methymnans) and F 233 (Tarentines), various aspects of luxury are recounted, but no explicit link is made between the presence of $\tau \rho \nu \varphi \dot{\eta}$ and any serious misfortune befalling the subjects. Nor are those few fragments in which a deleterious outcome is mentioned of such a kind as to illustrate a widely applicable historical principle: in $F 40$ the Ardiaeans, because of their fondness for feasting and drunkenness, are poisoned and destroyed by their enemies. In F 186 Hipparinus, the son of Dionysius, is murdered as a drunken tyrant. Finally, F 283 a relates that Dionysius the younger 'ruined his eyes with

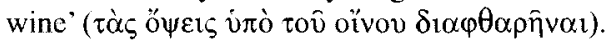

${ }^{70}$ We shall indicate below that there is some reason to believe that the wording of this sentiment is due to Athenaeus rather than Theopompus. 
a life is not proof against disaster. It seems that Athenaeus' focus is on what can happen not because of but in spite of $\tau \rho \nu \varphi \eta$. The same conclusion can be drawn from the fact that, after reporting Theopompus' testimony on Straton and Nicocles, Athenaeus tells us that Anaximenes told the

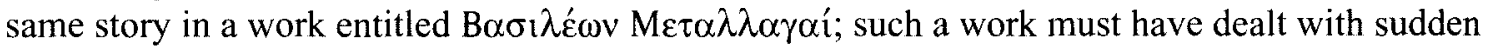
changes of royal fortune, whatever the cause. Thus, it seems wrong to conclude from $F 114$ that Theopompus thought that luxury engendered destruction. ${ }^{71}$

On the other hand, F 62 (= Athenaeus $12.526 \mathrm{~d}-\mathrm{f}$ ) appears, at least at first glance, to make the causal nexus patent. The Byzantines, it seems, had taught the Calchedonians democracy and worse:

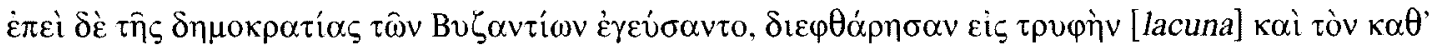

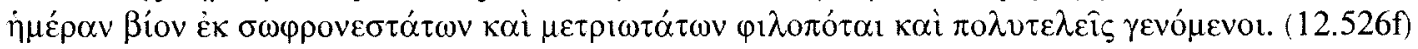

When they tasted the democracy of the Byzantines, they were ruined [lacuna] into luxury and, from being most measured and moderate in their daily lives, became drunkards and spendthrifts.

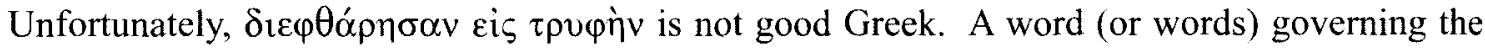
prepositional phrase has fallen out, and at a juncture of the text, moreover, whose correct interpretation is indispensable if we are to accept this passage as evidence on Theompompus' use of the idea of $\tau \rho v \varphi \eta$. To see the difference a single word might make in this regard, it is only necessary

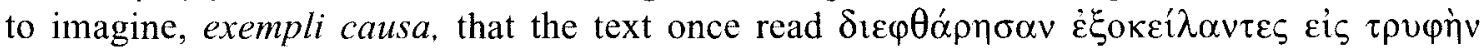

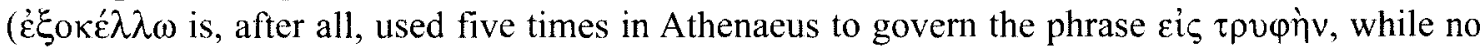
other verb is used more than once). In this case, the expression, if not the thought, would belong to the excerptor and not the historian. Of course, we cannot insist that $\dot{\varepsilon} \xi_{0} \varepsilon_{\varepsilon} i \lambda \alpha \nu \tau \varepsilon \zeta$ is the correct restoration here, but we do insist that the passage cannot be used to control the plausibility of our evaluation of the Sybarite $\tau \rho v \varphi \eta$ stories, since it may exhibit the same characteristics we are trying to explain. This fragment must be set aside. ${ }^{72}$

We have left to the last discussion of a passage that is, if one accepts the traditional interpretation, most pertinent to establishing the likelihood that $\tau \rho \varphi \varphi$ could have served in the period at issue to explain the destruction of Sybaris. Recall that the pathology of $\tau \rho v \varphi \eta$ at Sybaris is thought to have been of a very particular kind: prosperity led to luxury, which led to $\ddot{\beta} \rho \mathrm{\rho} \varsigma$, which led to divine anger and destruction. In the most recent examination of the question, Bernhardt is quite insistent on what he sees as the oldest tradition on the fall of Sybaris: 'Der Frevel gegen die Götter sei eine Folge der Hybris, die Hybris eine Folge des Luxus und der Luxus eine Folge übermässigen Reichtums gewesen.' ${ }^{73}$ We have tried to show that the evidence specifically about Sybaris which

\footnotetext{
7 Since the thrust of our argument aims to show how Athenaeus moulded his evidence to suit his purposes, we cannot assume that Athenaeus is here correctly representing Theopompus. It is possible that the historian gave $\tau \rho v \varphi \eta$ as a cause of the deaths of the two rulers, but that Athenaeus dropped this connection. The fact remains that we must begin our search for Theopompus' meaning with a correct interpretation of the fragment's context.

${ }^{72}$ In fact, this is no great loss for our understanding of

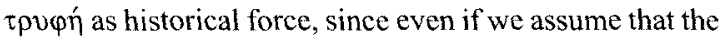
words and the thought are Theopompus', they would seem to have little historiographical significance. How did $\tau \rho \cup \varphi$ r ruin the people of Byzantium? It is possible to read

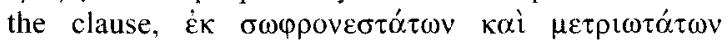

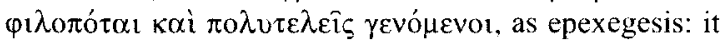
turned them into drunks, etc. In other words, the catastrophe referred to may be moral. No historical event need
}

then be cited to explain $\delta 1 \varepsilon \varphi \theta \dot{\alpha} \rho \eta \sigma \alpha v$. The verb is used similarly at $12.536 \mathrm{e}$ of Ptolemy Philadelphus, with a ruin that is strictly psychological: oú $\tau \omega \varsigma \grave{\varepsilon} \xi \alpha \pi \alpha \tau \eta \theta \hat{\eta} v \alpha \iota t$

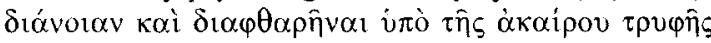

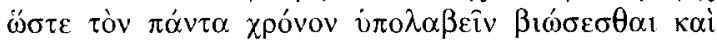

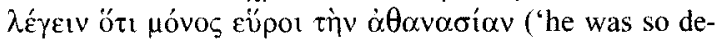
ceived in his reasoning and destroyed by unsuitable luxury that he thought he would live forever and that he alone had

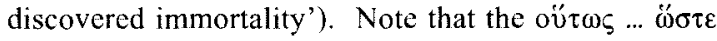
construction, being one of Athenaeus' favourite ways of introducing an example of $\tau \rho \cup \varphi \eta$, may indicate that he rather than Phylarchus, the named authority, is responsible for the wording here.

${ }^{73}$ Bernhardt (2003) 67. As we have noted, scholars consider this explanation 'Pythagorean'. This attribution is often supported by reference to Justin's epitome of Pompeius Trogus 4.1.2-6, 'Pythagoras ... Crotonam uenit pop- 
Athenaeus has preserved does not support this view, but Bernhardt also adduces the case of Colophon; he considers the history of this city a strong parallel for the sequence luxury-hybrisdestruction.

The key evidence is Athenaeus 12.526a-d, where that author quotes six verses of Xenophanes, perhaps the most well-known citizen of Archaic Colophon:

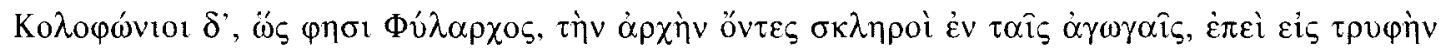

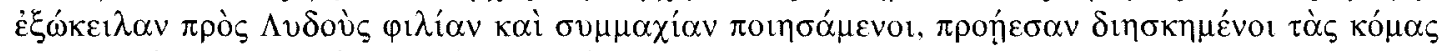

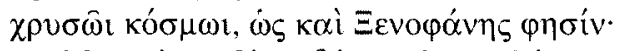

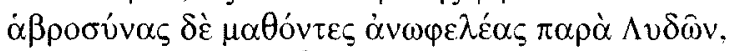

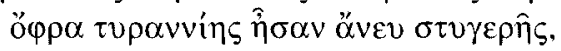

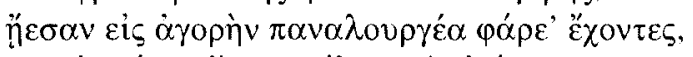

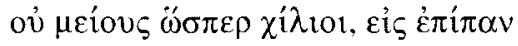

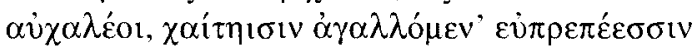

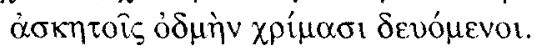

The Colophonians, as Phylarchus says, were originally severe in their training, but when they ran aground on luxury, having made an alliance of friendship with the Lydians, they used to go forth decked out with gold jewellery in their hair, as Xenophanes also says: 'Having learned useless luxuries from the Lydians, as long as they were without hateful tyranny, they would go to the agora wearing cloaks all of purple, no fewer than a thousand, for the most part, haughty, rejoicing in their fine tresses, drenched in oil artfully perfumed.'

There follows these lines an illustration of the Colophonians' propensity for strong drink, a description of a law regulating the working hours of flute-girls, a citation from Theopompus on the ancient price of purple and a concluding sentence summarizing the gist of the passage.

Since Bowra, scholars have accepted that this passage offers an early criticism of luxury based on political considerations. ${ }^{74}$ However, this view is probably made untenable by the characteristics of Athenaeus' method of citation that we have discussed above. Once again, we must beg off a thorough treatment of the subject due to the constraints of space. The salient points are these: Bowra assumes that Phylarchus and Theopompus must have known more of the poem than the lines cited here and that their interpretations were drawn from that information which is lost to us. We argue, on the contrary, that there are no details in this passage for which lost lines of Xeno-

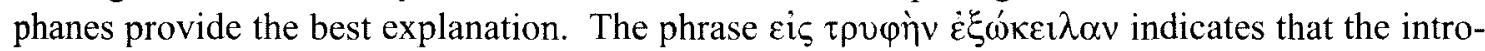
ductory sentence is Athenaeus' own formulation, despite the mention of Phylarchus. This point is

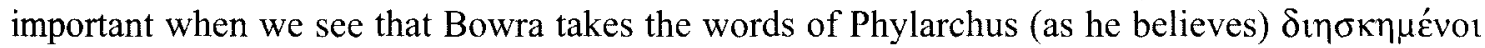

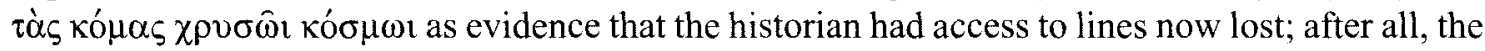
Xenophanes as quoted does not mention gold. Of course, this line of reasoning collapses when we realize that the mode of expression belongs to Athenaeus, for the Deipnosophist has just quoted

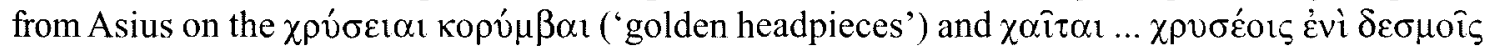
('tresses in golden bands') worn by the ancient Samians. In this context, it is not surprising if

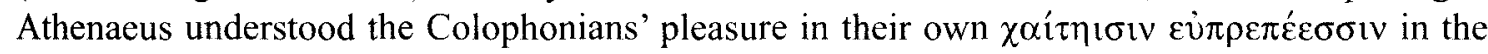
same way. ${ }^{75}$

ulumque in luxuriam lapsum auctoritate sua ad usum frugalitatis reuocauit. Laudabat cotidie uirtutem et uitia luxuriae casumque ciuitatium ea peste perditarum enumerabat' ('Pythagoras came to Croton and by his authority recalled a people sunk in luxury to the practice of moderation. Every day he used to praise virtue and list the vices of luxury and the downfall of cities ruined by that plague'). However, there is no doubt that in Pompeius' own day (the last decades of the first century $\mathrm{BC}$ ) luxuria could serve as an adequate explanation for civi- tates perditae. Given this ready source of contamination, the passage is hardly strong evidence for the political theories of Pythagoras or his followers 500 years earlier.

${ }^{74}$ Bowra (1941).

${ }^{75}$ Everything else in this first sentence can come from the quoted Xenophanes and Athenaeus' own powers of interpretation. The Colophonians' original sternness might be inferred from the fact that their luxuries were learned

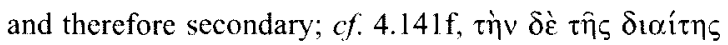

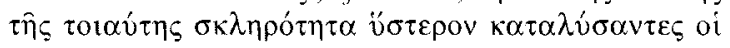


Bowra believes that the anecdote according to which some Colophonians were such drunkards that they saw neither sunrises nor sunsets 'looks like a paraphrase of actual words of Xenophanes', but the story certainly became a topos (Athenaeus tells it at $6.273 \mathrm{c}$ of Smindyrides and at $12.520 \mathrm{a}$ of the Sybarites in general), and could have been added by either Phylarchus or Athenaeus without

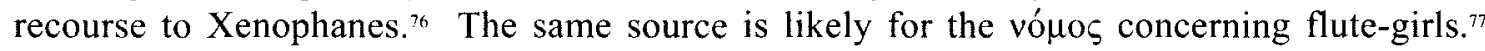
Theopompus' exegesis adds no significant information. The concluding sentence reports the destruction of Colophon because of stasis and tyranny - items not in the six lines of Xenophanes, but explanation is not difficult. Violence among citizens is a natural corollary of tyranny and thus a straightforward deduction from Xenophones' $\tau \rho \rho \alpha v v i ́ \eta ~ \sigma \tau v \gamma \varepsilon \rho \eta \dot{~}$, an inference especially easy to make given the notoriety of Colophon's subsequent ruin: the destruction of that city had provided an object lesson on the effects of ü $\beta$ pls from the time of Theognis. ${ }^{78}$ If, then, Athenaeus 12.526a$\mathrm{d}$ is the clearest evidence that can be mustered for the existence before the Hellenistic period of the idea that $\tau \rho v \varphi \eta$ begets $\ddot{\beta} \beta \rho \varsigma_{\varsigma}{ }^{79}$ that proposition is open to the strongest doubt. ${ }^{80}$

\section{CONCLUSIONS}

In view of the state of the scholarly argument on the historiographical use of $\tau \rho v \varphi \eta$, we feel that our position of scepticism is justified. In general, the place in Greek thought of $\tau \rho v \varphi \eta$ as an agent of historical change seems to have been quite limited before the beginning of the first century $\mathrm{BC}$,

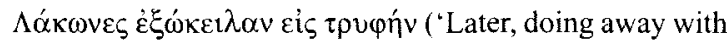
the sternness of such a way of life, the Laconians ran aground on luxury'). Just as easily the alliance and friendship between the two peoples might be derived from the apparent relationship between teacher and student.

${ }^{76}$ Again the oú $\tau \omega$... $\ddot{\sigma} \sigma \varepsilon$ construction makes us lean

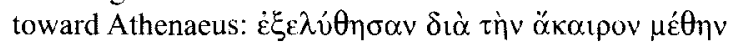

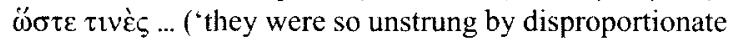
drunkenness that some ...').

${ }^{77}$ Phylarchus is the authority for other Archaic legislative oddities at $12.521 \mathrm{~b}-\mathrm{d}$.

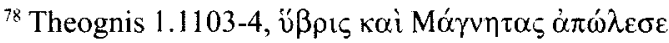

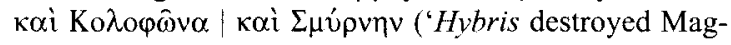
nesia and Colophon and Smyrna'). Even though the concluding sentence offers no additional insight into the thoughts of Xenophanes, we would like to know whether we should take these words as Theopompus' interpretation or a summation by Athenaeus. If by Theopompus, this would be a singularly clear example of that author giving $\tau \rho \cup \varphi n$ as a cause of a significant historical event. In favour of an attribution to Athenaeus, however, is the reoccurrence here of $\dot{\alpha} \gamma \omega \gamma \dot{m}$ from the introductory sentence (where it is surely Athenaeus' own wording, possibly sug-

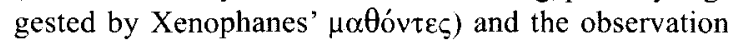
that Athenaeus is apt to end a $\tau \rho \nu \varphi \eta$ story with some such sentiment as 'they were destroyed': cf., e.g., $12.520 \mathrm{c}$

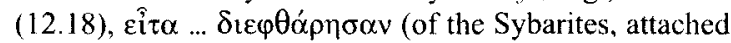

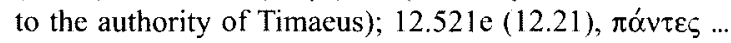
$\dot{\alpha} \pi \dot{\omega} \lambda$ ovto (Sybarites, Phylarchus); $12.521 \mathrm{f} \mathrm{(12.21),}$ $\delta 1 \varepsilon \varphi \theta \alpha ́ p \eta \sigma \alpha v$... $\alpha \pi \alpha v \tau \varepsilon \zeta$ (Sybarites, Heracleides Ponticus); 12.526ef (12.32), ӧ $\pi \alpha v \tau \varepsilon \varsigma . . . \delta ı \varphi \theta \theta \alpha \rho \eta \sigma \alpha v$ (Byzan-

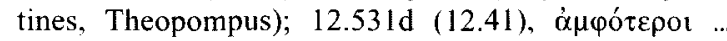
$\delta 1 \varepsilon \varphi \theta \alpha \dot{\rho} \eta \sigma \alpha v$ (Straton and Nicocles, Theopompus). The matter requires a closer investigation.

${ }^{79}$ Bowra (1941) 124 sees in Xenophanes' $\alpha \dot{\chi} \chi \alpha \lambda \lambda_{\text {ćot }}$ ('boastful, haughty') an allusion to 'a special form of ü $\beta \rho 15$, 'the arrogant display of wealth'. In his definitive study on í $\beta$ pls, Fisher (1992), esp. 19-21, 71, 113-15, does agree that displays of wealth can be hybristic, but only if they involve unfair seizure of property or unpitying injustice towards other people that brings shame and often violence upon those people. Simply spending money and wearing luxury items is not enough: someone must be dishonoured before an act can be classified as hybristic. Clearly, there is no such act in the fragment of Xenophanes, which Fisher does not mention, and we cannot read ü $\beta \rho ı$ into the luxury of the Colophonians on the basis of the superior attitude they adopted because of their dress. One may also note that there need be implied no causal relationship leading from $\alpha \beta \rho o \sigma u ́ v \alpha t-$ with or without $\ddot{\beta} \beta \rho t \zeta$ - to

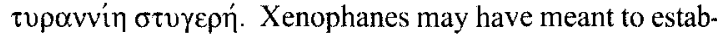
lish an antithesis between a time of luxurious living and the period of 'hateful tyranny' which followed.

${ }^{80}$ Frequently cited in support of this idea is Clearchus of Soli. Once again, what is taken to be the best evidence that Clearchus connected $\tau \rho \varphi \varphi \eta ́$ and $u ̈ \beta \rho ı$ is transmitted by Athenaeus and is compromised in a way that will by now be familiar to the reader. For example, $12.524 \mathrm{c}-\mathrm{d}$ (with similar cases at $12.522 \mathrm{~d}$ and $12.523 \mathrm{a}$ ): $\kappa \alpha \mathrm{i} \pi \varepsilon \rho \mathrm{i}$

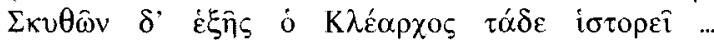

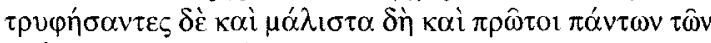

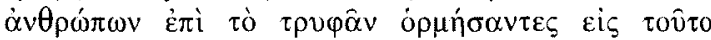

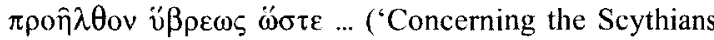
Clearchus goes on to write the following: ... indulging in luxury extremely and being the first of all peoples to set out eagerly after a luxurious life, they advanced to such a degree of insolence that ...'). In addition to the expression

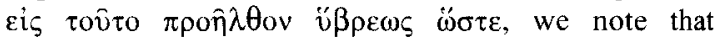
óp $\dot{\alpha} \rho \mu \hat{\eta} \sigma \alpha 1$ at $12.533 \mathrm{f}$ (both presented as Athenaeus' own

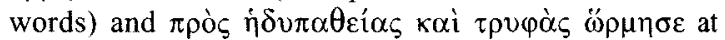
$12.521 \mathrm{e}$ (attached to the authority of Theopompus). The 
at least judged by the evidence usually brought forward. More narrowly, if Timaeus or Phylarchus did in fact explain that the fall of Sybaris was due to acts of $v \beta \beta$ they would be the earliest authors whom we know to make such a chain of cause and effect. The first occurrence in a direct transmission of evidence that $\tau \rho v \varphi \eta$ may lead to $\ddot{\beta} \beta \rho \imath \varsigma$ and then to dire

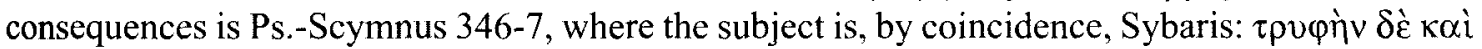

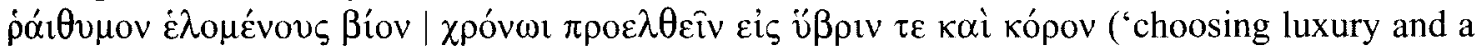
life of ease, in time they advanced into insolence and jadedness'). Given the ambiguities in Athenaeus' testimony which we have pointed out, it would be imprudent - perhaps even reckless - to attribute the origination of such a theory to one of these historians on the basis of material drawn from the Deipnosophistae."1

To summarize: our study of this topic has the following principal implications. (1) The Hellenistic tradition that the fall of Sybaris was an act of justice, in recompense for its $\tau \rho v \varphi \eta$ and $\ddot{\beta} \beta \rho 1 \zeta$, was anything but robust. Although Athenaeus' quotations of the testimony of Timaeus, especially, are frequently adduced to vouch for the strength of this tradition - and to justify a range of theories based on it - Athenaeus in fact supplies no reliably Hellenistic evidence explicitly connecting $\tau \rho \nu \varphi \eta$ and the destruction of the city. ${ }^{82}$ (2) The case of $\tau \rho v \varphi \eta$ is widely thought to be exemplary of the tendency among Hellenistic writers to explain historical events through moral causes. To the extent that it relies upon the evidence of Athenaeus, this view is seriously compromised. In every fragment we have examined, it is at least a strong possibility (and often demonstrable) that any formulation in which causative force is assigned to $\tau \rho v \varphi \eta$ is due not to the original authority, but to Athenaeus or an intermediary. To establish the relationship between this later formulation and the original text will require new investigations and fresh methods. (3) Detailed scrutiny of Athenaeus' discussion of $\tau \rho \cup \varphi \eta$ has revealed turns of phrase that can be identified as additions from the milieu of that author, even when he presents them as part of the quotation. We have no reason to be confident that we have noticed more than a small portion of such modes of expression or that their use is limited to Athenaeus' treatment of $\tau \rho \nu \varphi \eta$ or related subjects . A wide variety of modern views, if based on prose quotations by Athenaeus, may in fact rest not on good evidence but on the Procrustean interpretations of the Deipnosophist. In regard to each of these points, a full-scale study is clearly a desideratum.

\section{ROBERT J. GORMAN \\ VANESSA B. GORMAN University of Nebraska-Lincoln}

phraseology linking $\tau \rho \cup \varphi \eta ́$ and $u ́ \beta \rho \iota \varsigma$ patently belongs to Athenaeus. About Clearchus' beliefs we can draw no firm conclusion.

${ }^{81}$ One might also arrive at the same scepticism vis-àvis $\tau \rho u \varphi \eta$ by considering the entire extant collection of fragments for the authors we have discussed in connection with Sybaris. For Timaeus, for example, no other fragments offer any better evidence for his interest in $\tau \rho v \varphi \eta$ than those already examined: $F$ 1a and F $1 \mathrm{~b}$ tell of naked girls serving at table among the Etruscans; Athenaeus considers this a mark of luxury when he cites it at $12.517 \mathrm{~d}$, but not at $4.153 \mathrm{~d}$, where it is an exotic dining custom. In F $26 \mathrm{a}$ Timaeus may have offered $\tau \rho \nu \varphi \eta$ as a factor in the fall of Acragas to the Carthaginians, but interpretation is dependent on establishing the relationship of Diodorus Siculus towards his sources; this is far too controversial a basis on which to build a theory of moral causation in Timacus.

82 Leaving aside the passages transmitted by Athenaeus, there is little positive evidence on the fall of Sybaris before the first century BC. Herodotus, of course, speaks of the $\chi \lambda_{1} \delta \dot{\eta}$ of Smindyrides, and that Sybarite has become a symbol of hedonism by Aristotle's day ( $E E$ 1216a17). Aristophanes speaks of 'Sybaritic feasts' and uses the word $\sigma v \beta \alpha \rho \alpha^{\alpha} \zeta_{\varepsilon i v}$ in a sympotic context (Peace 344). No connection is drawn between Sybarite luxury and the city's destruction. In fact, Aristotle knows a dif-

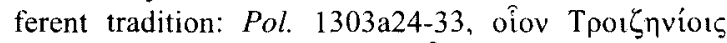

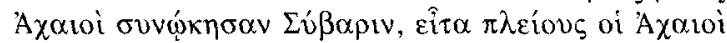

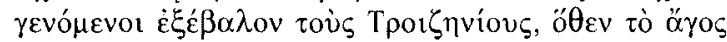

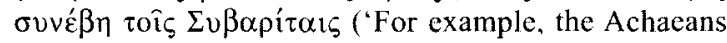
colonized Sybaris jointly with the Troezenians and then, when the Achaeans grew more numerous, they expelled the Troezenians. From this the curse befell the Sybarites'). To be sure, Aristotle records a moral cause for the Sybarites' misfortune; hence the 'curse' that seems to refer to the events of $510 \mathrm{BC}$. However, Aristotle's version is out of harmony with the $\tau \rho v \varphi \eta$ stories, which set the unjust actions leading to divine punishment in the last decades of the sixth century, when the city's prosperity was great. For Aristotle, the cause is to be sought in circumstances of the city's foundation in the last years of the eighth century. 


\section{BIBLIOGRAPHY}

Ambaglio, D. (1990) 'I Deipnosofisti di Ateneo e la tradizione storica frammentaria', Athenaeum 78 , 51-64

Ampolo, C. (1993) 'La città dell'eccesso: per la storia di Sibari fino al 510 a.C.', in Stazio and Ceccoli (1993) 213-54

Bernhardt, R. (2003) Luxuskritik und Alffwandsbeschränkungen in der griechischen Welt (Historia Einzelschrift 168, Stuttgart)

Bowra, C.M. (1941) 'Xenophanes, Fragment 3', CQ 35, 119-26

Braund, D. and Wilkins, J. (eds) (2000) Athenaeus and his World. Reading Greek Culture in the Roman Empire (Exeter)

Brown, T. (1958) Timaeus of Tauromenium (Berkeley and Los Angeles)

Brunt. P. (1980) 'On historical fragments and epitomes', CQ 30, 477-94

Bugno, M. (1999) Da Sibari a Thurii. La fine di un impero (Naples)

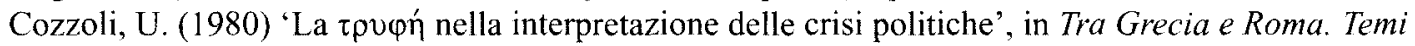
antichi e metodologie moderne (Rome) 133-46

del Corno, D. (1993) 'L'immagine di Sibari nella tradizione classica', in Stazio and Ceccoli (1993) 9-18

de Sensi Sestito, G. (1988) 'La storia italiota in Diodoro: considerazioni sulle fonti per i libri VII-XII', Critica storica 25, 403-28

Fisher, N. (1992) Hybris. A Study in the Values of Honour and Shame in Ancient Greece (Warminster)

Flashar, H. trans. (1981) Aristoteles: Mirabilia (Berlin)

Flower, M. (1994) Theopompus of Chios (Oxford)

Geffcken, J. (1892) Timaios' Geographie des Westens (Berlin)

Gorman, V.B. (2001) Miletos, the Ornament of Ionia (Ann Arbor)

Jacob, C. (2001) 'Ateneo, o il Dedalo delle parole', in L. Canfora (su progetto di), Ateneo, I Deipnosofisti: i dotti a banchetto (Rome) xi-cxvi

Lombardo, M. (1983) 'Habrosyne e habrá nel mondo greco arcaico', in Modes de contacts et processus de transformation dans les sociétés antiques. Actes du colloque de Cortone (24-30 mai 1981) (Pisa and Rome) $1077-1103$

Nenci, G. (1983) 'Tryphé e colonizzazione', in Modes de contacts et processus de transformation dans les sociétés antiques. Actes du colloque de Cortone (24-30 mai 1981) (Pisa and Rome) 1019-30

Nyikos, L. (1941) Athenaeus quo consilio quibusque usus subsidiis Dipnosophistarum libros composuerit (Basel)

Passerini, A. (1934) 'La TPY ФH nella storiographia ellenistica', Studi italiani di filologia classica 11, $35-56$

Pelling, C.B.R. (1979) 'Plutarch's method of work in the Roman Lives', JHS 99, 74-96.

- (1985) 'Plutarch and Catiline', Hermes 113, 311-29

- (2000) 'Fun with fragments', in Braund and Wilkins (2000) 171-90

Stazio, A. and Ceccoli, S. (eds) (1993) Sibari e la Sibaritide. Atti del trentaduesimo Convegno di studi sulla Magna Grecia, Taranto-Sibari, 7-12 Ottobre 1992 (Taranto)

Van der Stockt, L. (1999) 'A Plutarchan hypomnema on self-love', AJPh 120, 575-99

Vattuone, R. (1991) Sapienza d'occidente. Il pensiero storico di Timeo di Tauromenio (Bologna)

Walbank, F. (2000) 'Athenaeus and Polybius', in Braund and Wilkins (2000) 161-9

Zecchini, G. (1989) La cultura storica di Ateneo (Milan) 